\title{
Restoration of deficient DNA Repair Genes Mitigates Genome Instability and Increases Productivity of Chinese Hamster Ovary Cells
}

Philipp N. Spahn ${ }^{1,2, \#}$, Xiaolin Zhang,"\#, Qing Hu${ }^{4}$, Nathaniel K. Hamaker ${ }^{3}$, Hooman Hefzi Shangzhong $\mathrm{Li}^{5}$, Chih-Chung Kuo ${ }^{5}$, Yingxiang Huang ${ }^{1}$, Jamie C. Lee ${ }^{1,5}$, Peter Ly ${ }^{4}$, Kelvin H. Lee $^{3, *} \&$ Nathan E. Lewis ${ }^{1,2,5, *}$

${ }^{1}$ Department of Pediatrics, University of California, San Diego, La Jolla, CA 92093

2 The Novo Nordisk Foundation Center for Biosustainability at the University of California, San Diego School of Medicine, San Diego, La Jolla, CA 92093

${ }^{3}$ Department of Chemical and Biomolecular Engineering, University of Delaware, Newark, DE 19711

${ }^{4}$ Department of Pathology, University of Texas Southwestern Medical Center, Dallas, TX 75390

${ }^{5}$ Department of Bioengineering, University of California, San Diego, La Jolla, CA 92093

\# Equal contribution

* Corresponding authors: Kelvin H. Lee, khl@udel.edu; Nathan E. Lewis, n4lewis@eng.ucsd.edu

Keywords: Genome instability, systems biology, cell line instability, CHO, DNA repair, biotechnology 


\section{Abstract}

Chinese Hamster Ovary $(\mathrm{CHO})$ cells are the primary host used for manufacturing of therapeutic proteins. However, production instability of high-titer cell lines is a major problem and is associated with genome instability, as chromosomal aberrations reduce transgene copy number and decrease protein titer. We analyzed whole-genome sequencing data from $11 \mathrm{CHO}$ cell lines and found deleterious single-nucleotide polymorphisms (SNPs) in DNA repair genes. Comparison with other mammalian cells confirmed DNA repair is compromised in $\mathrm{CHO}$. Restoration of key DNA repair genes by SNP reversal or expression of intact cDNAs improved DNA repair and genome stability. Moreover, the restoration of LIG4 and XRCC6 in a $\mathrm{CHO}$ cell line expressing secreted alkaline phosphatase mitigated transgene copy loss and improved protein titer retention. These results show for the first time that correction of key DNA repair genes yields considerable improvements in stability and protein expression in $\mathrm{CHO}$, and provide new opportunities for cell line development and a more efficient and sustainable production of therapeutic proteins. 


\section{Introduction}

Chinese Hamster Ovary $(\mathrm{CHO})$ cells have been the leading expression system for the industrial production of therapeutic proteins for over 40 years, and projections show they will maintain this dominant position into the foreseeable future because they produce $>80 \%$ of therapeutic proteins approved between 2014-2018 corresponding to more than $\$ 100$ billion of products per year $[1,2]$. Steady improvements in cell line development, media formulation, and bioprocessing now enable production yields exceeding $10 \mathrm{~g} / \mathrm{L}$ from a fed-batch culture. Emerging resources, including the $\mathrm{CHO}$ and hamster genome sequence [3-8] and genome editing tools [9-14] now allow researchers to rely less on largely empirical, "trial-and-error" approaches to $\mathrm{CHO}$ cell line development, and move towards a more rational engineering approach, in pursuit of novel $\mathrm{CHO}$ lines with tailored, superior attributes [15-18].

However, cell line instability, i.e. the propensity of a cell line to lose industrially relevant properties over time, remains a challenging problem in the field as it can result in loss of titer, changes in product quality, or changes in cell growth potentially impacting manufacturing and drug supply. Thus, considerable effort is expended to ensure that production clones are stable for use in fed-batch production (for example, that a given clone retains $70 \%$ of its titer after 60 generations in culture which would be deemed a "stable" producer [19]). However, as the field moves toward perfusion and continuous culture, cell line stability remains a key challenge to overcome.

Production instability can arise from transcriptional transgene silencing through epigenetic mechanisms, such as promoter methylation or histone acetylation [20-26]. However, while such epigenetic transcriptional silencing was associated with production instability in some studies, a loss in transgene copy number due to genome instability (i.e. the rapid accumulation of mutations and chromosome aberrations) appears to be predominant cause of production instability [20, 22, 27-33]. The inability to maintain genome integrity will negatively affect production stability in most, if not all, production cell lines during long-term culture. Because massive transgene expression imposes a high metabolic demand on the host, the random loss of these transgenes is effectively under positive selection in the bioreactor, causing the emergence of non-producing subpopulations that can outgrow the remaining producers in the pool, resulting in titer decline. 
Genome instability is common across cancers, and can arise from defects in DNA damage repair [34]. In $\mathrm{CHO}$, genome instability was first reported in the 1970 s when direct observations of $\mathrm{CHO}$ chromosomes revealed a divergence from the Chinese hamster (Cricetulus griseus) karyotype and variability in karyotypes among $\mathrm{CHO}$ clones $[35,36]$. These karyotype variations occur regardless of growth condition, and do not differ markedly between pooled and clonal populations [37-39]. Loss of chromosomal material and improper chromosome fusions (translocations) are caused by improperly repaired double-strand breaks (DSBs) $[40,41]$ which result from metabolic processes, such as attack by free radicals or collapsed DNA replication forks [41]. Given that primary cells from the Chinese hamster do not show genome instability, DSB repair ability is likely compromised in CHO. Thus, identifying and restoring deficient DSB repair genes in $\mathrm{CHO}$ cells could effectively enhance the DSB repair system, mitigate genome instability, and improve product titer stability.

To date, few studies have addressed the persistent genome instability problem in $\mathrm{CHO}$ cells, and it has been challenging to develop effective counterstrategies. Detailed quantification of chromosomal instabilities in production cell lines has indicated that certain chromosome sites are less prone to instability than others [42]. This observation has suggested that transgene loss may be avoided by targeting transgenes to these stable chromosomal areas, an option now possible through the development of targeted transgene integration techniques [12, 43-45]. Further studies used gene knock-outs ( $A T R$ and $B R C A 1$, respectively) to increase product titer by increasing transgene copy number amplification [46, 47], but whether these knock-outs are able to sustain high production in long-term culture has remained unclear. Thus, a pressing need remains for novel approaches to mitigate production instability stemming from DSBs. Although the mechanistic connections between production instability and DNA DSBs are evident, the field has not systematically explored the engineering of DNA repair as a possible means to reduce transgene loss in $\mathrm{CHO}$. Inactivation of ATR was shown to result in an increase in transgene copies during the amplification phase, but also a less rigid cell cycle control and higher chromosomal instability [46], which might exacerbate production instability in the long run. Therefore, rather than inactivating DNA repair genes for short-term gains, rescue of deficient DNA repair could constitute a promising approach to achieve long-term improvement in stability.

Here we investigate the relationship between DSB repair and genome instability in $\mathrm{CHO}$ cells. We describe the landscape of mutations in DNA repair genes across a panel of 11 commonly used $\mathrm{CHO}$ 
lines, and show that DSB repair ability is compromised in $\mathrm{CHO}$ compared to other mammalian cell lines. We then show that restoration of key DSB repair genes yields significant improvements in repair ability and genome stability. Finally, we show in a proof-of-concept experiment that restoration of DNA repair genes XRCC6 and LIG4 improves the stability of transgene copy number and protein titer in a long-term-culturing study in a $\mathrm{CHO}$ cell line secreting alkaline phosphatase (SEAP). 


\section{Results}

\section{CHO cells are deficient in DSB repair}

To test if DSB repair is deficient in CHO cells, we compared DSB repair between CHO-K1 and bEnd.3 and BHK-21, two established and well characterized mammalian cell lines. An endogenous DSB level was first estimated by counting the number of $\mathrm{yH} 2 \mathrm{AX}$ foci per cell. $\mathrm{yH} 2 \mathrm{AX}$ denotes phosphorylated histone H2AX in the chromatin area surrounding a DSB which often extends several megabases from the break site, visible as a focus in confocal microscopy [48]. Quantification of $\mathrm{YH} 2 \mathrm{AX}$ foci is a well-established method to visualize unrepaired DSBs as H2AX is dephosphorylated only after initiation of repair [49]. The number of endogenous DSBs in CHO-K1 was significantly higher than in BHK-21 cells (Fig. 1b,c: untreated). CHO cells also had more endogenous DSBs than bEnd.3 cells, although the difference was less pronounced (Fig. 1b,c: untreated). We next tested the repair ability in these cell lines after treatment with bleomycin, a DSB-inducing drug. A 12hour treatment $(10 \mu \mathrm{g} / \mathrm{mL})$ allowed sufficient passive diffusion across the cellular membrane, and remaining DSBs were counted at different time-points during the recovery period (Fig. 1a). bEnd.3 cells showed the fewest DSBs with an average of 12 foci per nucleus $1 \mathrm{~h}$ after bleomycin removal, and a reduction to an average of 1.5 foci per nucleus after $24 \mathrm{~h}$ (Fig. 1b,c; $1.0 \mathrm{DSBs} / \mathrm{hour}$ by linear regression). BHK-21 cells showed comparable DNA damage to $\mathrm{CHO}$ cells $1 \mathrm{~h}$ after bleomycin removal, but a fast reduction to an average of 4 foci per nucleus after 24h (Fig. 1b,c; 2.6 DSBs/hour by linear regression). CHO-K1 showed the slowest DSB repair rate (Fig. 2b,c; 0.9 DSBs/hour by linear regression) and the most remaining DSBs after $24 \mathrm{~h}$ of recovery, showing that DSB repair is compromised in $\mathrm{CHO}$ cells.

\section{CHO cells contain numerous mutations in genome stability genes}

To assess the extent of mutations in DNA repair genes, we analyzed whole-genome sequencing (WGS) data of $11 \mathrm{CHO}$ cell lines, including those commonly used for cell line development in biopharmaceutical production (e.g. CHO-S, CHO-XB11, CHO-DG44) (Table 1). We extracted a list of genes related to genome stability from a curated database [50], and aligned the respective $\mathrm{CHO}$ homologs to the Chinese hamster genome $[4,5]$. We looked for single-nucleotide polymorphisms (SNPs) and short indels ( $<10 \mathrm{bp})$, located in exons, and used a phylogeny-based 
score to predict the deleteriousness of these mutations on gene function (PROVEAN score) [51]. All $11 \mathrm{CHO}$ lines were heavily affected by SNPs in DNA repair genes. We identified 157 mutations in various genes spanning 14 ontology classes (Fig 2a; Suppl Fig. 1). Using copy-number information derived from the WGS datasets, we retained only mutations which had undergone a loss of heterozygosity since these can typically be expected to have higher impacts on phenotype. After this filtering, the most conserved and most deleterious mutations occurred in genes related to nonhomologous end-joining, DNA-damage sensing, and in helicases all of which are relevant for maintenance of genome stability (Fig. 2b).

\section{Restoration of DNA repair genes leads to an improved DNA damage response}

Of the likely deleterious mutations (Fig. 2b), we selected critical DSB repair carrying conserved mutations across the cell lines in our dataset. In mammalian DNA repair, the protein kinase Ataxia-telangiectasia mutated (ATM) is among the first factors to become activated upon persistent DSBs that are not resolved by simple ligation, and instead require more advanced processing, such as end-resection, before repair can be attempted $[52,53]$. ATM is thus a key upstream player in the DNA-damage response to DSBs (Fig. 2c) [54]. All $11 \mathrm{CHO}$ cell lines carry a SNP in the catalytic PI3K/PI4K domain $(\mathrm{R} 2830 \mathrm{H})$, predicted to be highly deleterious according to PROVEAN scoring which made it a promising target for SNP correction. Downstream of ATM, DSB repair occurs through two main pathways: non-homologous end-joining (NHEJ) and homology-directed repair (HDR) [55]. In HDR, a sequence template homologous to the damaged strand is utilized to produce an error-free repair of the DNA lesion. In NHEJ, DNA ends from both sides of the lesion are ligated without using homology information which often implies loss of basepairs. While HDR is clearly preferable for maintaining sequence integrity, its activation requires homologous sequences which are only available during S- and G2-phase, but unavailable during the longer G1 phase. In addition, mutations in HDR genes were less widespread among $\mathrm{CHO}$ cell lines (Fig. 2b). Thus, we reasoned that restoration of NHEJ would be of primary importance to improve DNA repair in $\mathrm{CHO}$ and mitigate chromosomal instability and transgene loss. PRKDC is the catalytic subunit of the DNA-PK (DNAdependent protein kinase) complex that becomes active early during NHEJ to shield loose chromosome ends at a break site and initiate ligation [56]. In our dataset, all $11 \mathrm{CHO}$ cell lines carry two SNPs in PRKDC, both predicted to be detrimental. Thus, given its key role in NHEJ and this 
widespread occurrence, we reasoned that PRKDC would be another high-priority target for gene correction efforts. We prioritized SNP D1641N in the FAT domain over S3419G due its PROVEAN score indicating higher deleteriousness.

Using CRISPR/Cas9-mediated gene correction protocols (Integrated DNA Technologies), we generated a clonal CHO-K1 population with a successful reversal of R2830H in ATM (hereafter referred to as $\mathrm{CHO}-\mathrm{K} 1 \mathrm{ATM}^{+}$). From this population, we generated a sub-clone with a successful reversal of D1641N in PRKDC (hereafter referred to as CHO-K1 $\mathrm{ATM}^{+} \mathrm{PRKDC}^{+}$) (Fig. 2d). These reversals were done in succession to assess the cumulative effect of DNA repair improvements. RNA-seq of the new cell lines $\mathrm{ATM}^{+}$and $\mathrm{ATM}^{+} \mathrm{PRKDC}^{+}$revealed only few differentially expressed genes, and gene set enrichment analysis did not identify significantly up-/downregulated pathways (Suppl. Fig. 2), consistent with these SNP reversals not having detrimental effects on viability or metabolism. In a parallel approach, we generated cell lines expressing intact copies of XRCC6 and LIG4, cloned from Chinese hamster tissue (Fig. 2e. Hereafter referred to as CHO-K1 CMV::XRCC6 and CHO-K1 CMV::LIG4), which both carry likely detrimental SNPs (XRCC6 Q606H and LIG4 L145I and C741R). These genes were chosen despite the heterozygosity of these SNPs considering the critical roles these genes play in non-homologous end-joining [57].

To assess improvement in DSB repair capability, we implemented a GFP-based reporter system in $\mathrm{CHO}$ (based on the EJ5-GFP reporter developed for cancer cells [58]) that allows quantification of DSB repair through flow cytometry as sequence loss from compromised DSB repair causes GFP expression (Fig. 3a,b). We validated the assay in CHO-K1 wildtype cells treated with KU-60019, a highly effective small-molecule inhibitor against the ATM kinase, which caused a significant increase in the fraction of GFP+ positive cells, indicating compromised DSB repair (Fig. 3c). This also indicates that the $\mathrm{R} 2830 \mathrm{H}$ mutation in $A T M$ in $\mathrm{CHO}-\mathrm{K} 1$ represents a hypomorphic allele since, otherwise, chemical inhibition of ATM would not have exacerbated the repair deficiency. Interestingly, CHO-K1 $\mathrm{ATM}^{+}$showed a significant decrease in the fraction of GFP positive cells, indicating a successful improvement in repair of the induced lesion (Fig. 3c). Even further improvement of repair ability was seen in ATM+ PRKDC+ (Fig. 3c). CHO cells overexpressing intact XRCC6 or LIG4 copies also showed a reduction in GFP positive cells (Fig. 3d), indicating successful improvement in DSB repair ability in these cell lines. 
To rule out effects potentially specific to the described GFP reporter, we analyzed DSB repair efficiency more generally, through immunostaining against $\mathrm{YH} 2 \mathrm{AX}$. In $\mathrm{CHO}-\mathrm{K} 1$, low levels of $\mathrm{YH} 2 \mathrm{AX}$ foci are visible even in the absence of any DSB-generating treatments, corresponding to the endogenous origins of DSBs (Fig. 3e,f: left). We note that the generation of $\mathrm{yH} 2 \mathrm{AX}$ is partially dependent on the ATM kinase [59] which likely explains why under untreated conditions foci numbers were slightly higher in cell lines carrying a restored ATM gene (Fig. 3e: left) as these cells likely mark damaged sites more effectively. In contrast, CMV::XRCC6 and CMV::LIG4 showed lower numbers of endogenous DNA damage foci (Fig. 3f: left). To compare repair efficiency after a strong DNA insult, we applied bleomycin treatment as described above, and found fewer foci in the ATM+ PRKDC+ and CMV::LIG4 cell lines, compared to CHO-K1 WT, after a 24h recovery period (Fig. 3e,f: middle). To rule out different rates of bleomycin uptake between cell lines [60], we also induced DNA damage with exposure to 0.5 Gy of X-ray irradiation. Foci enumeration after $2 \mathrm{~h}$ of recovery showed improved DSB repair efficiency in all engineered cell lines compared to wildtype CHO-K1 (Fig. 3e,f: right). Thus, the DSB repair machinery is more active in the engineered cell lines and yields improved response to ubiquitous DNA damage, not specific to a break triggered at a specific site.

\section{Restoration of DNA repair improves genome stability in $\mathrm{CHO}$}

Unrepaired DSBs can lead to chromosomal aberrations, ultimately driving loss of transgene expression. We thus asked whether the improvements in the DNA damage response in the engineered $\mathrm{CHO}$ cell lines would improve the overall state of genome integrity. For this, we first exposed wildtype and engineered cell lines to DSB-inducing conditions and analyzed genome integrity on the single-cell level by electrophoresis where both the length and the intensity of the resulting DNA tail is an indicator of the amount of genome fragmentation (comet assay). After exposing cells to bleomycin or radiation, we noticed considerable DNA displacement in wildtype $\mathrm{CHO}$ cells, with some cells exhibiting very long, bulky DNA tails indicating severe genome fragmentation due to persistent DSBs (Fig. 4a,b: middle and right). Restoration of ATM resulted in minor changes in DNA tail length, but additional restoration of $P R K D C$ led to a strong reduction in both tail length and intensity, and we did not detect long bulky DNA tails in these samples (Fig. 4a: middle and right). These results are consistent with ATM acting as a DNA damage sensor [54], not a bona fide DNA repair gene, which likely explains why rescue of ATM alone had limited effects. Importantly, also in 
the absence of genotoxic stress, ATM+ PRKDC+ showed very short DNA tails, indicating improved genome stability (Fig. 4a: left). We also observed shorter DNA tails in CMV::XRCC6 and CMV::LIG4 cell lines across all conditions (Fig. 4b). Together, these results indicate that restoration of key genes controlling non-homologous end-joining successfully enhances DNA repair and reduces genome fragmentation. We noticed several chromosome aberrations in the parental $\mathrm{CHO}-\mathrm{K} 1$ strain, from which the engineered cell lines were derived, such as translocations, e.g. on chromosomes \#3, \#6, or \#7, and whole chromosome duplications, e.g. \#4 and loss of X-chromosomes (Fig. 4c). In a long-term culture experiment, where cell lines were passaged in parallel over a 60-day period, ATM+ and ATM+ PRKDC+ cell lines acquired considerably fewer additional chromosome aberrations than the parental wildtype cell line (Fig. 4d,e), consistent with improved genome stability. Another wildtype sample, supplemented with $3 \mu \mathrm{M}$ KU-60019, served as a positive control and acquired many more aberrations, resulting in almost $75 \%$ of karyotypes deviating from the parental main karyotype (Fig. 4d,e). In summary, while $\mathrm{CHO}$ cells carry a high burden in DNA repair genes, restoration of just few key genes can improve DSBs repair as well as structural chromosomal stability.

\section{Restoration of DNA repair improves titer stability in a producing cell line}

Based on the notion that genome instability can disrupt the maintenance of high protein titers in industrial biomanufacturing, we reasoned that genome stabilization could counteract this problem by slowing the loss of transgene copies caused by chromosome instability. The results above support the notion that restoration of DNA repair genes could help stabilize protein titers. Thus, we applied this strategy in CHO-SEAP, an adherent cell line expressing human secreted alkaline phosphatase (SEAP) [61]. Guided by our results for non-producing CHO-K1, we generated CHO-SEAP cell lines expressing Chinese hamster wildtype copies of XRCC6 and LIG4, respectively. These cell lines, CHO-SEAP CMV::XRCC6 and CMV::LIG4, showed significantly improved DSB repair ability, evident as a reduction of GFP positive cells in the EJ5-GFP assay (Fig. 5a) and in DNA repair foci (Fig. 5b). Surprisingly, reversals of ATM R2830H and PRKDC D1641N in CHO-SEAP CMV::XRCC6 did not yield further improvements, but instead caused a decrease in DSB-repair ability (Fig. 5a). Consistent with this observation, chemical inhibition of ATM resulted in a slight improvement in repair ability (Fig. 5a), in contrast to our observations in CHO-K1 (See Discussion). 
Because both XRCC6 and LIG4 overexpression had beneficial effects on genome stability in CHO-SEAP, we next grew clonal populations of CHO-SEAP WT, CMV::XRCC6, and CMV::LIG4 in parallel over a 74-day period and compared both SEAP titer and SEAP transgene copy number at the beginning and the end of the experiment. Prior to the start of the experiment, cells were cultured in 5 $\mu \mathrm{M}$ methotrexate (MTX) for 1 week to select for high SEAP copy number amplification, after which MTX was taken off the growth medium. MTX is a competitive inhibitor of dihydrofolate reductase, an essential metabolic enzyme, which is co-expressed with the transgenic SEAP locus [61]. In all cell lines, SEAP titer retention (=titer at day 74 , relative to day 0 ) correlated significantly with SEAP copy number retention (Fig. 5c), highlighting the importance of genome stability as a determinant of cell line productivity. CHO-SEAP WT cells retained about $75 \%$ of the initial SEAP titer on average, but a considerable fraction of clones showed dramatic titer decline to as low as 10\% (Fig. 5c: left). Clones overexpressing LIG4 showed improvements in stability of both titer and copy number although results were only marginally statistically significant (Fig. 5c: right; Fig. 5d). XRCC6 overexpression, however, gained significant stabilization of both SEAP titer and copy number, retaining about $90 \%$ SEAP titer on average, and showing fewer cases of dramatic titer decline, with the minimum titer retention at 30\% (Fig. 5c: middle; Fig. 5d). Together, these results show that rescue of non-homologous endjoining in $\mathrm{CHO}$ cells successfully mitigates transgene loss and titer decline. 


\section{Discussion}

The CHO-based platform in biologics manufacturing is well-established, but an important unsolved problem is genome instability, which causes a population derived from a clonal cell to display genetic heterogeneity. Apart from few studies identifying impaired repair pathways $[62,63]$, this is the first report documenting the full extent of mutations affecting DNA repair genes across $\mathrm{CHO}$ cell lines. Moreover, while reactivation of silenced DNA repair genes has been successfully implemented before [64], restoration of DNA repair ability has not yet been systematically explored to mitigate genome instability in cell line development. This study is the first report to show that restoring DNA repair function through genome editing ameliorates genome stability in $\mathrm{CHO}$. Furthermore, we showed that despite the high mutational burden in DNA repair genes, restoration of just a single gene can yield significant improvements in genome integrity. This makes DNA repair restoration a powerful and feasible novel addition to the cell line engineering toolbox. Our dataset of mutated DNA repair genes opens up a plethora of options for future studies, targeting single genes or combinations of genes to develop novel cell lines for biopharmaceutical manufacturing. While effective alternative approaches have recently been described to increase $\mathrm{CHO}$ cell productivity, such as overexpression of key metabolic genes [65], suppression of apoptosis [13], or design of novel promoters [66], restoration of DNA repair tackles the mechanistic root of genome instability and could enable long-lasting stability improvements. Beyond protein expression, restoration of DNA repair genes could prove effective in other aspects of cell line engineering, for example by improving rates of targeted gene integration or gene correction in $\mathrm{CHO}$ [67]. Also, the approach could be expanded to other cell lines.

As shown here, improvement of DSB repair ability appears to occur in an incremental fashion when combinations of DNA repair genes are being restored, provided these genes work synergistically, as ATM and PRKDC do in CHO-K1, for example, evident from the gradual improvement in repair ability when combining both gene corrections (Fig. 3c). However, selecting the optimal gene targets, or combination of gene targets, for DNA repair rescue remains challenging. While data on human cancers, DNA repair, or evolutionary conservation [68] can guide selection of likely effective candidate genes, our data shows that restoration of even the same genes can yield different outcomes in different cell lines (Fig. 5a). Given the divergent genomes of different $\mathrm{CHO}$ cell lineages [5] and the complex, intertwined nature of the mammalian DSB repair cascade [57], results from one cell line may not necessarily apply likewise to others. In mammals, DSB repair follows a "decision tree" [57] where 
pathway choice is largely determined by the severity of the DNA lesion. In particular, while a core NHEJ pathway can act independently of ATM $[57,69]$, ATM plays a key role in initiating repair of lesions requiring more pre-processing and more advanced repair pathways, such as homologydirected repair (HDR), alternative end-joining (aEJ), or the Fanconi anemia (FA) pathway [57, 70, 71]. For this repair system to be effective, genes in these pathways downstream of ATM need to be functional. Thus, it is possible that in $\mathrm{CHO}-\mathrm{K} 1$ these pathways have retained higher functionality than in CHO-SEAP which would explain why activating ATM in CHO-SEAP has detrimental outcomes. Indeed, our dataset shows a higher incidence of SNPs in HDR or FA pathways in CHO-SEAP (a DXB11 derivative) compared to CHO-K1 (Suppl. Fig. 1). Thus, in CHO-SEAP, ATM restoration might have triggered a negative net effect with downstream pathways being largely incapacitated, especially since the competition between pathways could inhibit functional NHEJ [72]. Previous studies reported similar unexpected effects upon inhibition of DNA repair genes, such as ATM or MRE11 [67, 73]. Observing such opposite effects in different $\mathrm{CHO}$ cells after rescuing identical genes provides a promising model platform to study synergistic gene relationships and competition within the DSB repair hierarchy. Unlike $A T M$, restoration of $X R C C 6$ resulted in a considerable improvement in DSB repair in both CHO-K1 and CHO-SEAP, although the SNP $(\mathrm{Q} 606 \mathrm{H})$ in XRCC6 is only heterozygous. Yet, Ku70 (the protein encoded by XRCC6) binds to Ku80 to form the heterodimeric Ku complex, and mutations in XRCC6 are thus likely to cause a dominant phenotype. Indeed, in human cells, a heterozygous Ku80 mutation can trigger increased genome instability [74]. Thus, target choice for gene correction needs to be carefully considered. Developing a high-throughput screening method will therefore be highly valuable to identify optimal gene targets. The EJ5-GFP cell line described in this study can serve as an excellent discovery tool that could be utilized in flow-cytometry screens to identify optimal targets for DNA repair enhancement for this purpose. Certainly, the EJ5-GFP assay is approximate due to the possibility of false negative signal (i.e. a reporter site that did not get cut despite the presence of Cas9:miRFP, or a reporter site whose loose ends failed to merge entirely), but it still provides a good estimate of DSB repair ability since positive GFP expression can only occur after imperfect DSB repair processing. Further, cell line stabilization efforts targeting enhancement of DNA repair have to occur late in the cell line development process since transgene copy number amplification requires high genome plasticity. Thus, for optimal efficacy, genome stabilization preferably needs to occur after a high-producing clone has been isolated. 
In conclusion, this study provides the first thorough documentation of the deficient DNA repair machinery in $\mathrm{CHO}$ cells, and constitutes a proof-of-concept of the notion of DNA repair restoration as a powerful novel method for cell line development in industrial protein expression to ensure stable upstream manufacturing processes. 


\section{Tables}

Table 1: Genome sequences of $\mathrm{CHO}$ cell lines analyzed in this study.

\begin{tabular}{|c|c|c|}
\hline Cell line & Origin & $\begin{array}{c}\text { NCBI Sequence Read } \\
\text { Archive Number }\end{array}$ \\
\hline $\mathrm{CHO}-\mathrm{K} 1$ & ATCC & SRP045758 \\
\hline $\mathrm{CHO}-\mathrm{K} 1$ & ECACC & SRS406579 \\
\hline $\mathrm{CHO}-\mathrm{K} 1 / \mathrm{SF}$ & ECACC & SRS406580 \\
\hline $\mathrm{CHO}$ protein-free & ECACC & SRS406578 \\
\hline CHO-DG44 & Life Technologies & SRS406582 \\
\hline $\mathrm{CHO}-\mathrm{S}$ & Life Technologies & SRS406581 \\
\hline $\mathrm{CHO}-\mathrm{S}$ & $\begin{array}{l}\text { Clone from the Technical University of Denmark } \\
\text { (derived from Life Technologies) }\end{array}$ & (unpublished) \\
\hline C0101 & $\begin{array}{l}\text { Undisclosed company (Drug producing cell line } \\
\text { derived from CHO-S from Life Technologies) }\end{array}$ & SRX258098 \\
\hline $\mathrm{CHO}-\mathrm{Z}$ & $\begin{array}{l}\text { Clone from the Technical University of Denmark } \\
\text { (Serum-free suspension adapted clone derived } \\
\text { from an ECACC CHO-K1 clone) }\end{array}$ & (unpublished) \\
\hline CHO-DXB11 & Clone from the Technical University of Denmark & SRX689758 \\
\hline CHO-pgsA-745 & ATCC & (unpublished) \\
\hline
\end{tabular}




\section{Figures}

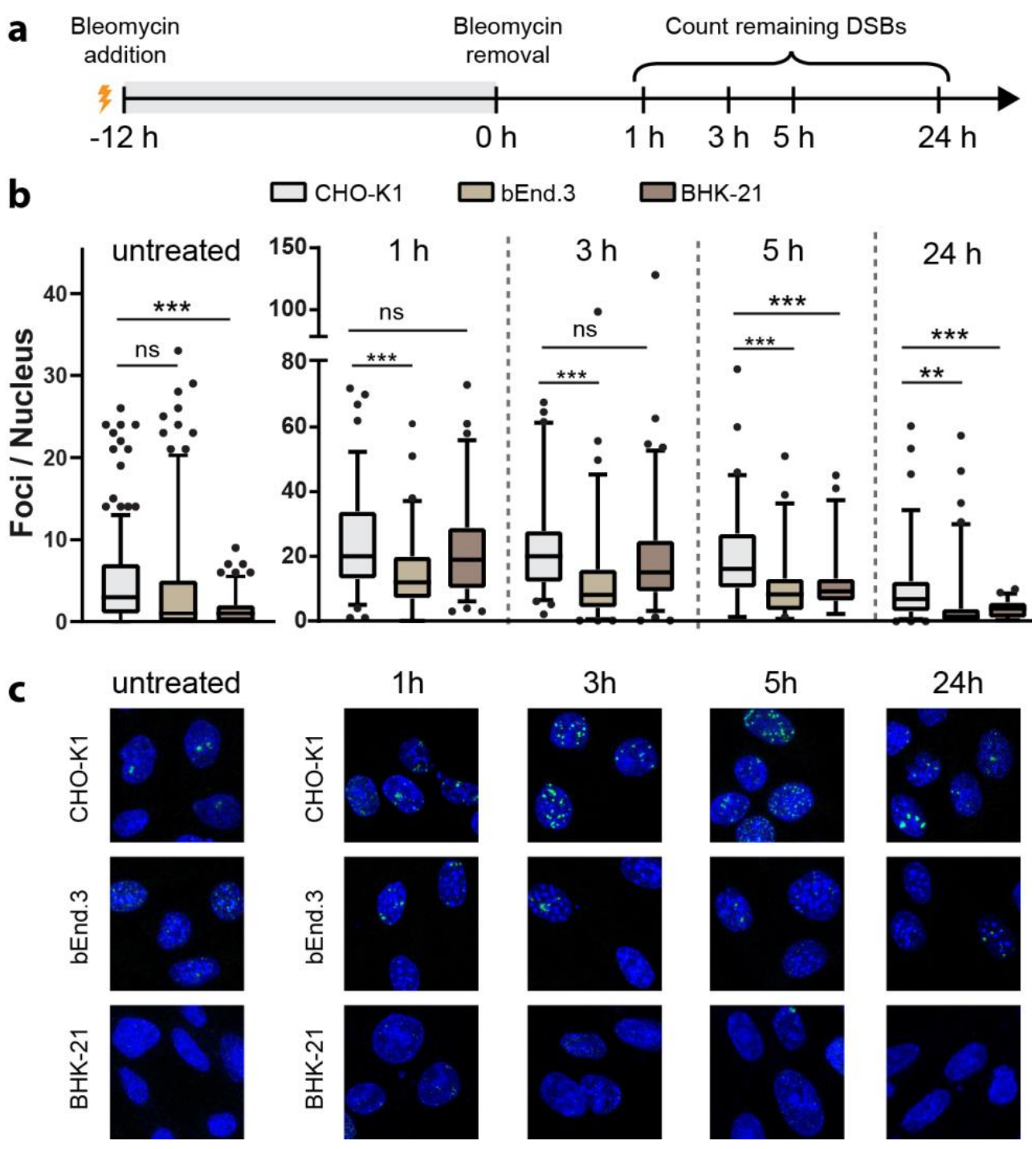

Fig. 1: DSB repair ability in CHO cells and primary cells. (a): Method of bleomycin treatment:

Cells were incubated in $10 \mu \mathrm{g} / \mathrm{mL}$ bleomycin for 12 hours, after which bleomycin was removed, wells were rinsed with DPBS, and cells were left in full growth medium without bleomycin for the indicated time periods for recovery before fixation. (b): Enumeration of $\mathrm{yH} 2 \mathrm{AX}$ foci in $\mathrm{CHO}-\mathrm{K} 1$, bEnd.3, and BHK-21 cells without bleomycin treatment (left) and after bleomycin treatment and the indicated recovery intervals. Welch's t-tests. untreated: $n \geq 129$ nuclei, $1 \mathrm{~h}: \mathrm{n} \geq 63$ nuclei, $3 \mathrm{~h}: \mathrm{n} \geq 66$ nuclei, $5 \mathrm{~h}: \mathrm{n} \geq 45$ nuclei, 24h: $n \geq 42$ nuclei. Whiskers showing 5/95-percentiles. (c): Immunostainings against $y H 2 A X$ in CHO-K1 wildtype, bEnd.3, and BHK-21 cells, corresponding with the conditions in (b). Cells counterstained with DAPI. 
a Number of SNPs 102030

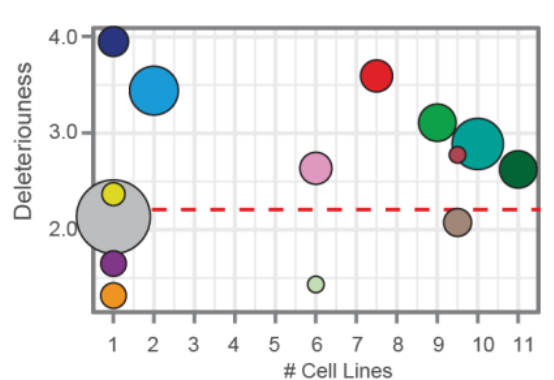

b Number of SNPs (5) (10) 15

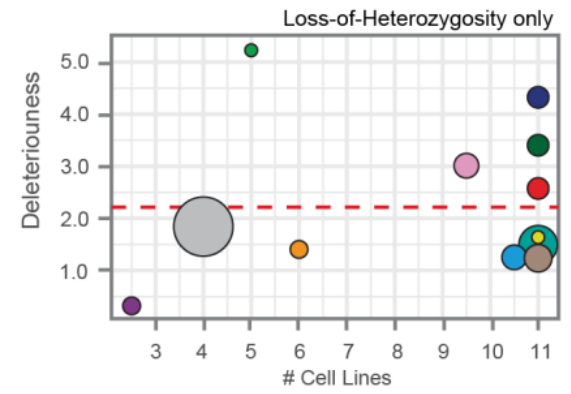

Base excision
repair

Cell cycle
control

Chromatin
modification

Chromosome
segregation

DNA damage
sensing

DNA replication
Fanconi anem

- Helicases

Homology-
directed repair
Mismatch repair $0 \begin{aligned} & \text { Single-strand } \\ & \text { break repair }\end{aligned}$

Non-homologous
end-joining

Nucleotide-

excision repair

\section{C}
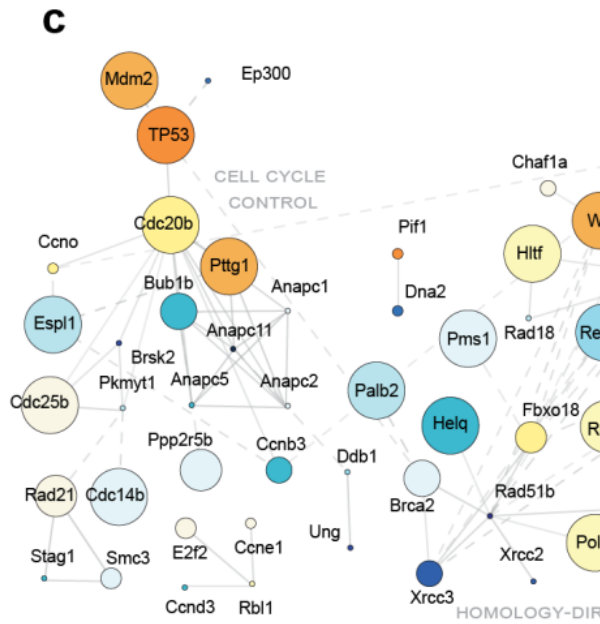

Helq Fbxo18 Rmi1 Fance Brip1

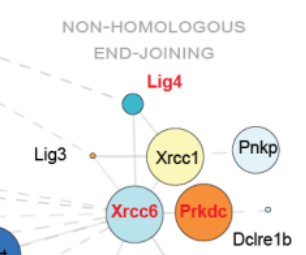

$\bigcirc_{\text {Brca2 }}$ Rad51b

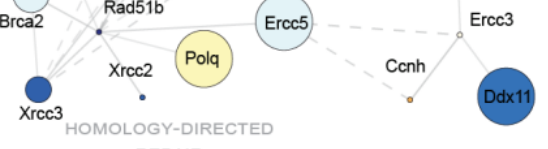

REPAIR

Number of cell lines carrying mutation:
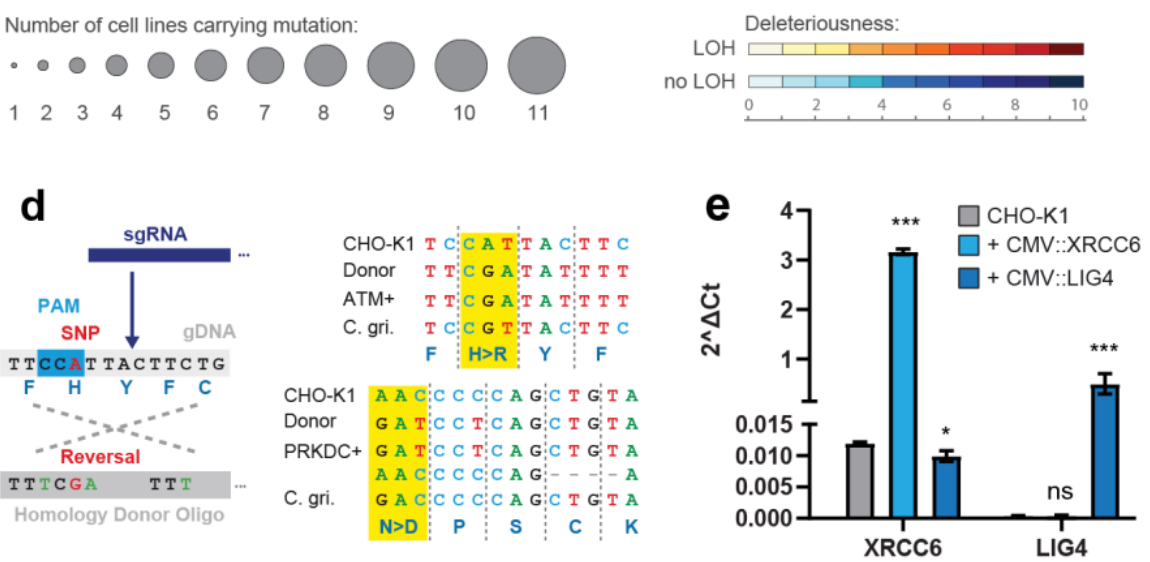

Fig. 2: DNA repair mutation landscape in CHO. (a): Mutations found in whole-genome sequencing data from 11 major $\mathrm{CHO}$ cell lines, categorized into 14 gene ontology groups (bottom legend) related to genome stability. The number of $\mathrm{CHO}$ lines carrying each mutation and the predicted deleteriousness are averaged across all mutations in each ontology group (x-axis: median of cell lines affected; $y$-axis: average negative PROVEAN score). The dashed line indicates the recommended threshold (2.282) to separate neutral from detrimental SNPs [51]. In total, 157 mutations are shown. 
(b): Subset of mutations shown in (a) that have undergone loss of heterozygosity, i.e. having lost the Chinese hamster wildtype allele at the respective locus (62 mutations total). (c): Protein-protein interaction network of genes carrying mutations in at least one $\mathrm{CHO}$ cell line. Number of $\mathrm{CHO}$ cell lines carrying each mutation is displayed by bubble size. Color represents predicted deleteriousness (negative PROVEAN score) and loss of heterozygosity (LOH). In cases where multiple mutations were found in a gene, the most conserved one is shown. The network is grouped into 4 clusters based on protein-protein interaction score with connections across clusters shown by dashed lines. Genes not participating in a cluster were omitted for clarity. Genes in red were selected for rescue in this study. (d): Left: SNP reversal is carried out by targeting an sgRNA to a PAM (NGG, reverse strand displayed) proximal to the respective SNP (red). A ssDNA homology donor oligo carrying the reversed base (red) is provided as a repair template carrying additional, silent SNPs (green) to prevent re-targeting of the repaired sequence. Right: Sequence alignment of targeted SNP loci in ATM (R2830H, top) and PRKDC (D1641N, bottom). CHO-K1: host strain, Donor: homology oligo template, ATM+/PRKDC+: cell clones obtained from SNP reversal (PRKDC+ is short for ATM+ PRKDC+), C. gri: Chinese hamster (Cricetulus griseus). (e): Relative transcript abundance of XRCC6 and LIG4 in CHO-K1 WT (grey), CHO-K1 CMV::XRCC6 (light blue), and CHO-K1 CMV::LIG4 (dark blue). Welch's t-test after $\log _{2}$-transformation, $n=3$. 

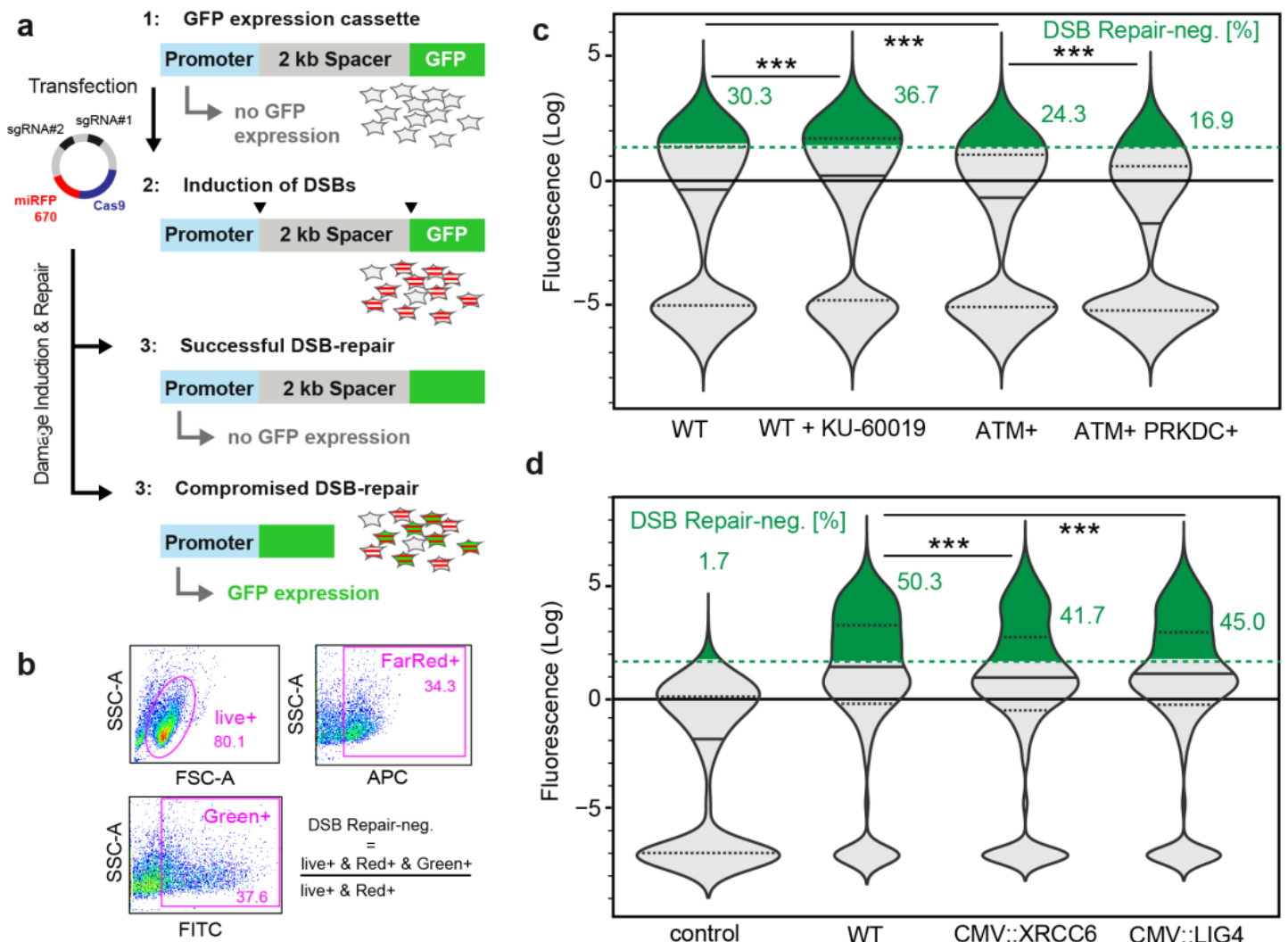

d

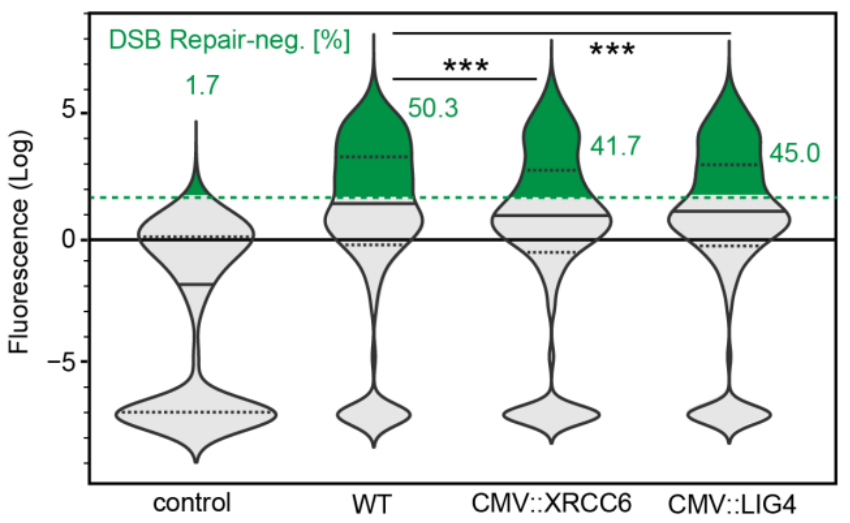

e

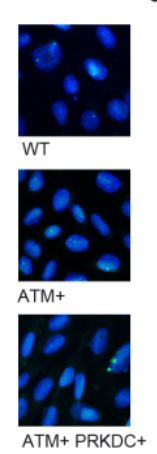

untreated

Bleomycin

X-Ray Irradiation
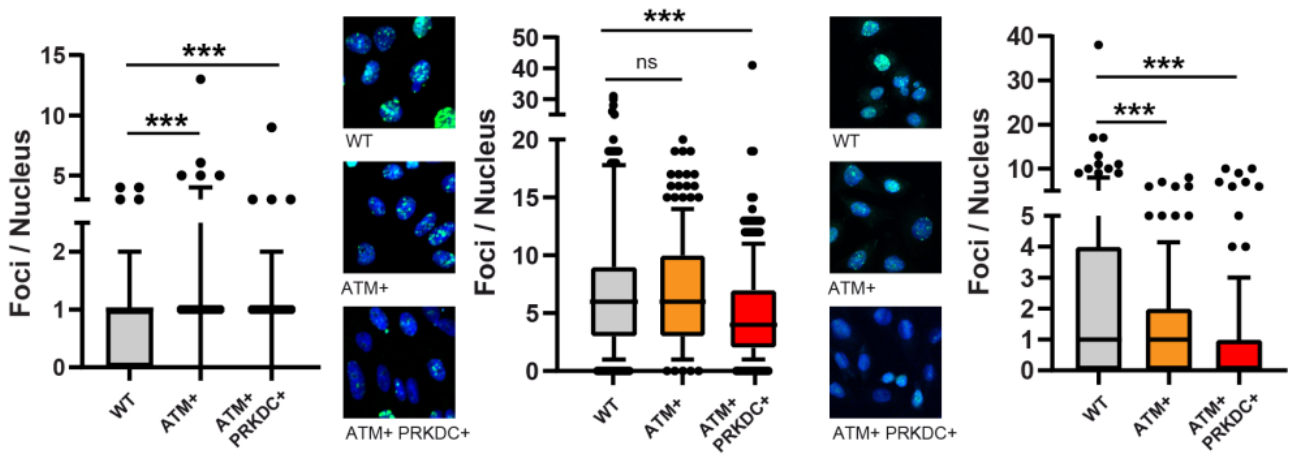

f

$\mathrm{DAPI} \bullet \mathrm{YH} 2 \mathrm{AX} \bullet$

untreated

Bleomycin
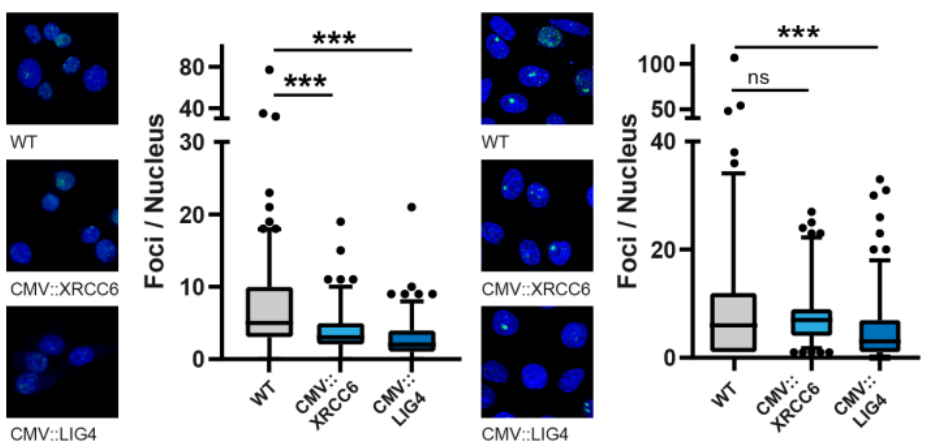

X-Ray Irradiation
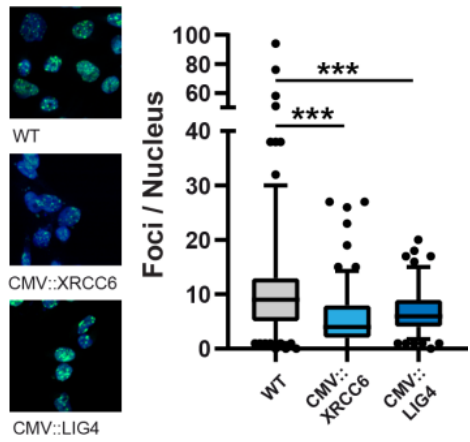

Fig. 3: Analysis of DNA repair ability after gene rescue. (a): Step 1: The EJ5-GFP cassette comprises a promoter, a $2 \mathrm{~kb}$ spacer, and a GFP reading frame. The spacer prevents the promoter 
from driving GFP expression. Step 2: Transient transfection with a DSB-inducing plasmid, encoding Cas9 and two sgRNAs, targets two sites at the 5' and 3' ends of the spacer. Successfully transfected cells are identified through far-red fluorescence of the Cas9:miRFP670 protein. Step 3: Transfected cells that repair both DSBs properly keep the spacer in place and remain GFP-negative. Transfected cells that lose the spacer due to compromised DNA repair become GFP-positive (assay modified from [58]). (b): DSB repair ability is quantified through flow cytometry by relating the fraction of GFPpositive cells to all transfected cells, with the gates shown. (c): Violin plots of GFP signal in FarRed+ cells of the indicated genotypes. Data showing pooled populations from three independent transfections per genotype. Green dashed line: GFP intensity threshold. Two-sample KolmogorovSmirnov tests, $n \geq 6,700$ cells. (d): Violin plots of GFP signal in FarRed+ cells of the indicated genotypes. control: WT cells, not transfected with the DSB-inducing plasmid (not displayed in (c)). Data showing pooled populations from three independent transfections per genotype. Green dashed line: GFP intensity threshold. Two-sample Kolmogorov-Smirnov tests, $n \geq 4,500$ cells. Different percentages of GFP+ cells in WT cells across different experiments are caused by differences in transfection rates and recovery periods after transfection. (e): Immunostainings against $\mathrm{YH} 2 \mathrm{AX}$ in CHO-K1 wildtype, ATM+, ATM+ PRKDC+. Left: untreated cells, $n \geq 115$ cells. Middle: Cells treated with $10 \mu \mathrm{g} / \mathrm{mL}$ bleomycin ( $24 \mathrm{~h}$ recovery), $\mathrm{n} \geq 405$ cells. Right: Cells treated with 0.5 Gy X-ray radiation (2h recovery), $n \geq 196$ cells. Welch's t-tests. (f): Immunostainings against $\mathrm{yH} 2 \mathrm{AX}$ in CHO-K1 wildtype, CMV::XRCC6, CMV::LIG4. Left: untreated cells, $\mathrm{n} \geq 140$ cells. Middle: Cells treated with $10 \mu \mathrm{g} / \mathrm{mL}$ bleomycin (24h recovery), $\mathrm{n} \geq 114$ cells. Right: Cells treated with 0.5 Gy X-ray radiation ( $2 \mathrm{~h}$ recovery), $n \geq 134$ cells. Welch's t-tests. Whiskers showing 5/95-quantiles. Cells counterstained with DAPI. 
a

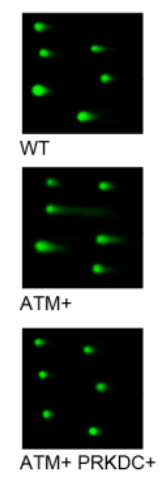

b

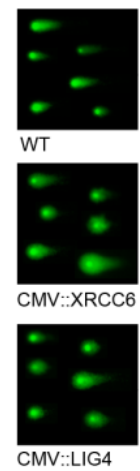

untreated

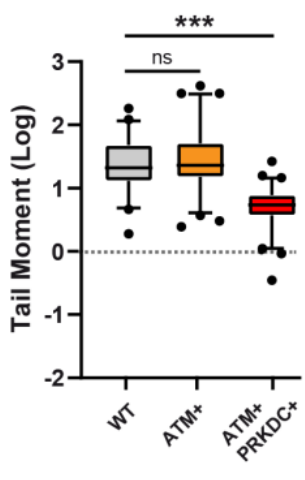

untreated

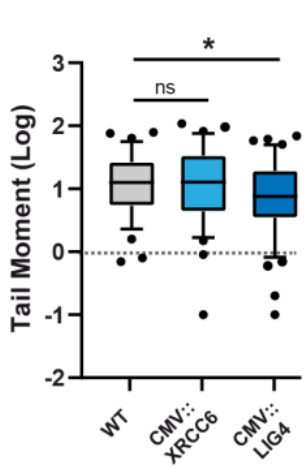

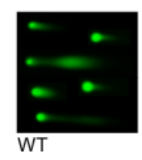

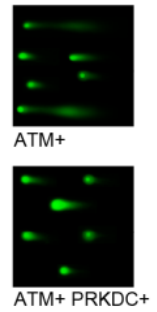

ATM+PRKDC+
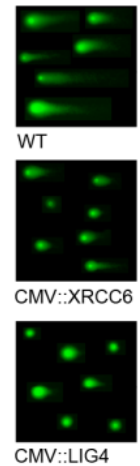

Bleomycin

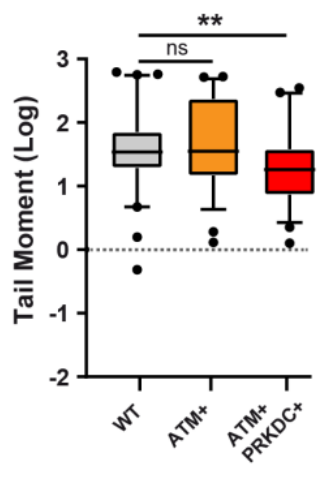

Bleomycin

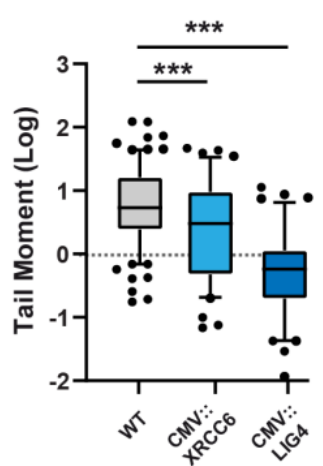

X-Ray Irradiation
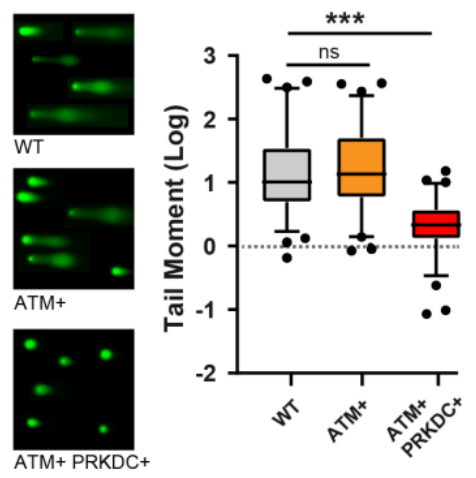

X-Ray Irradiation
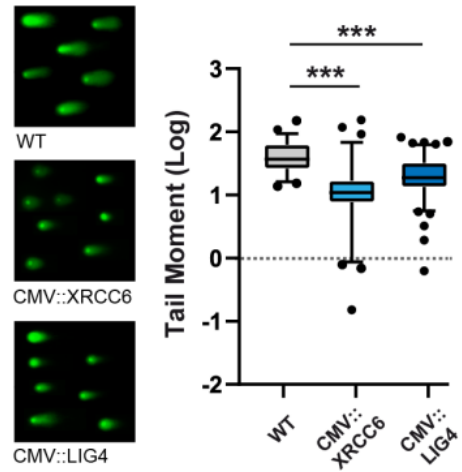

C Main Karyotype

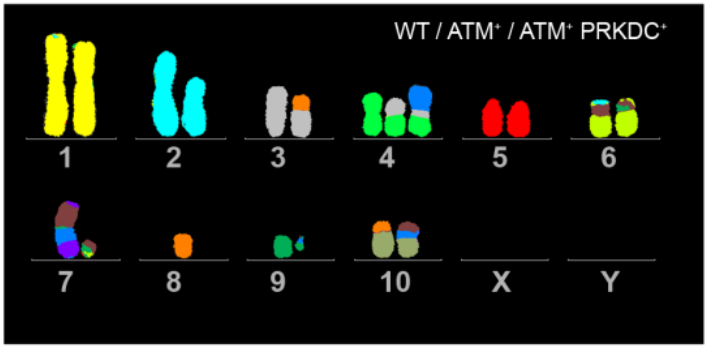

e Karyotype Variations

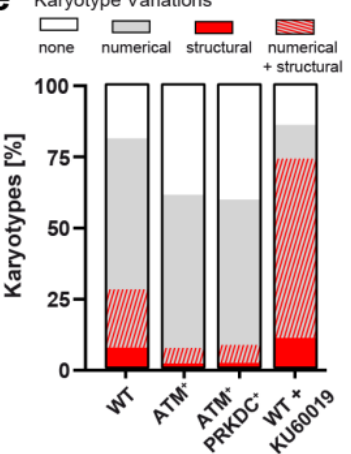

d Karyotype Deviations (Examples)

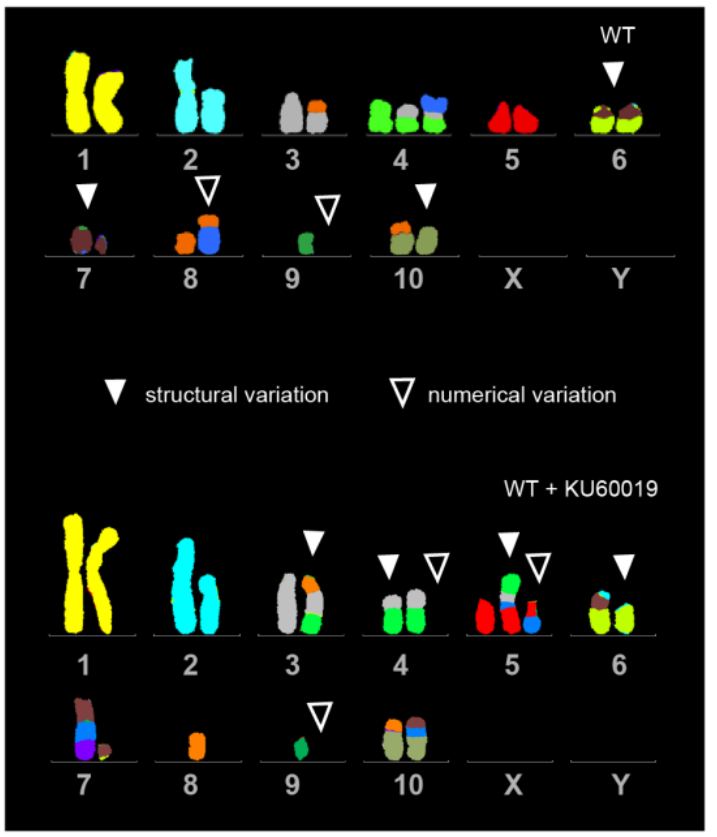

Fig. 4: Analysis of genome stability after gene rescue. (a): Representative composite images and tail moments (=tail length*DNA in tail [\%]) of wildtype, ATM+ and ATM+ PRKDC+ cells after electrophoresis in a low-melting agar (comet assay). Left: untreated cells, $n \geq 53$ cells. Middle: Cells 
treated with $10 \mu \mathrm{g} / \mathrm{mL}$ bleomycin (24h recovery), $\mathrm{n} \geq 56$ cells. Right: Cells treated with 0.5 Gy X-ray radiation ( $2 \mathrm{~h}$ recovery), $\mathrm{n} \geq 71$ cells. Welch's t-tests. Whiskers showing 5/95-quantiles. (b): Representative composite images and tail moments (=tail length*DNA in tail [\%]) of wildtype, CMV::XRCC6 and CMV::LIG4 cells. Left: untreated cells, $\mathrm{n} \geq 74$ cells. Middle: Cells treated with 10 $\mu \mathrm{g} / \mathrm{mL}$ bleomycin ( $24 \mathrm{~h}$ recovery), $\mathrm{n} \geq 86$ cells. Right: Cells treated with 0.5 Gy X-ray radiation ( $2 \mathrm{~h}$ recovery), $n \geq 57$ cells. Welch's t-tests. Whiskers showing 5/95-quantiles. (c): Main karyotype after 60 passages of long-term culture. Chromosomes were identified using pseudo-color probes, specific for each Cricetulus griseus chromosome. (d): Examples for deviating karyotypes in WT (top) and WT, supplemented with KU-60019 (bottom). Open arrows indicate a numerical variation (i.e. gain/loss of a chromosome), closed arrows indicate a structural variation (i.e. an altered color pattern). (e): Left: Classification of karyotypes into: (i) showing at least one numerical variation with no structural variations (grey), (ii) showing at least one structural variation with no numerical variations (red), (iii) showing both at least one numerical and at least one structural variation (grey/red striped), and (iv) showing no variations (white), relative to the main karyotype (c). Differences in frequency of structural variations (red and red/grey fractions) significant at 5\% level (Binomial test) (asterisks omitted for clarity). Averaged fractions from duplicate experiments: WT $n=26 / 34 ; A T M+n=21 / 37 ; A T M+P R K D C+$ n=21/37; WT+KU60019 n=8/19. Right: Total number of chromosomes per karyotype. Bar = median. Non-parametric ANOVA (Kruskal-Wallis test). 
a
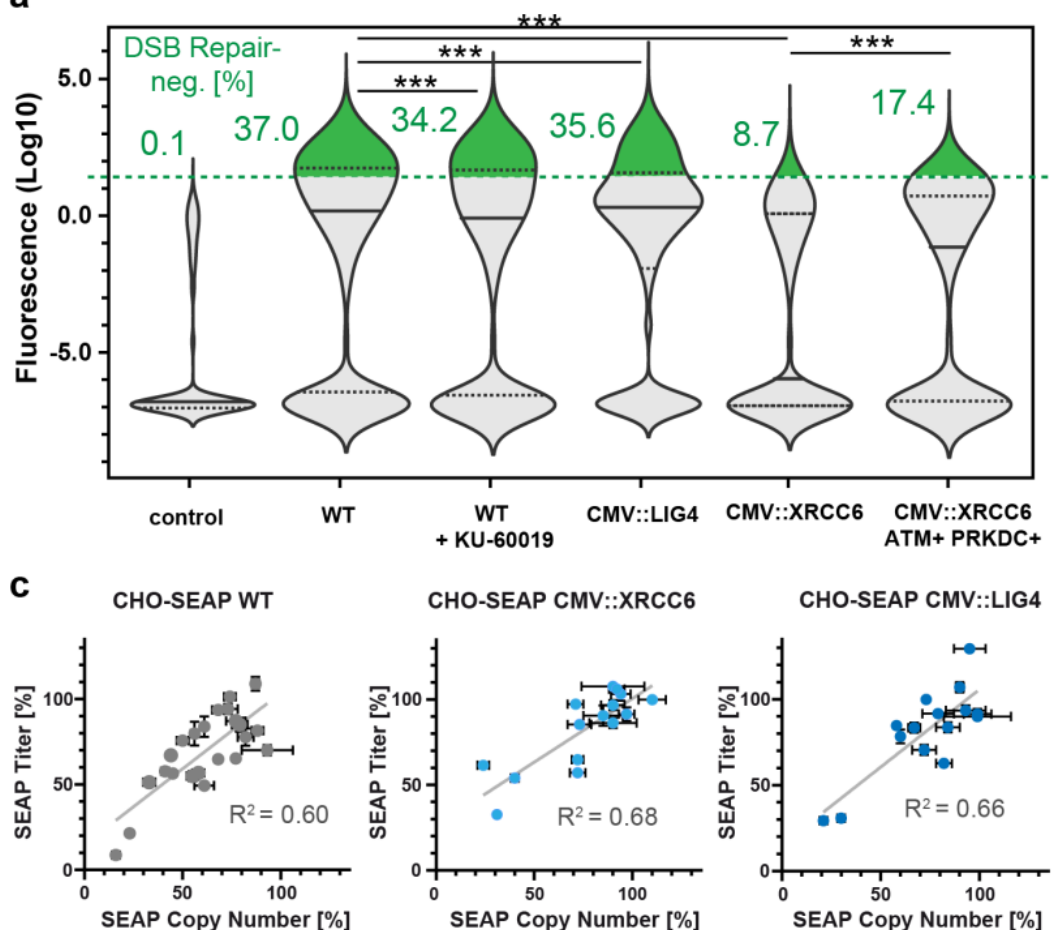

CHO-SEAP CMV::XRCC6

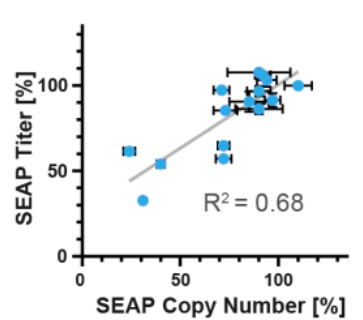

CHO-SEAP CMV::LIG4

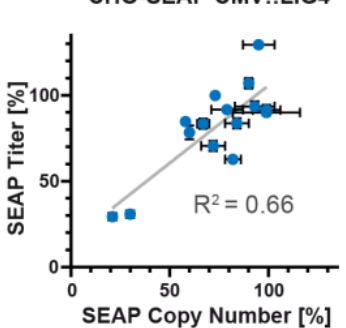

b
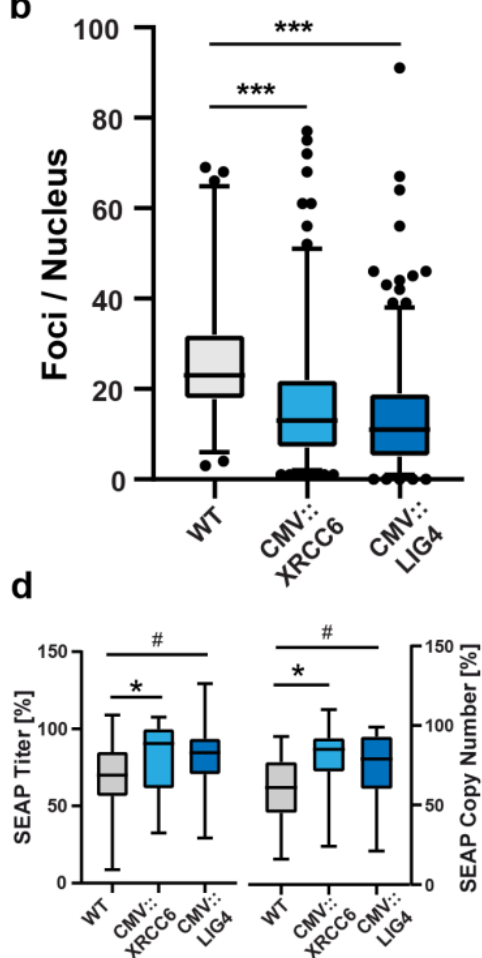

Fig. 5: DSB repair and protein titer in a producing $\mathrm{CHO}$ cell line. (a): Violin plots of GFP signal in FarRed+ cells of the indicated genotypes in CHO-SEAP. control: WT cells not transfected with the DSB-inducing plasmid. Data showing pooled populations from two independent transfections per cell line. Green dashed line: GFP intensity threshold. Two-sample Kolmogorov-Smirnov tests. $n \geq 3,800$ cells. (b): Immunostainings against yH2AX in CHO-SEAP wildtype, CMV::XRCC6, and CMV::LIG4. Cells treated with $10 \mu \mathrm{g} / \mathrm{mL}$ bleomycin (24h recovery). Pooled data from 4 representative clones per genotype. $n \geq 134$ cells. Welch's t-tests. Whiskers showing 2.5/97.5-quantiles. (c): SEAP titer change versus SEAP gene copy number change in clonal populations of the indicated genotypes over a longtime culture period of 74 days. Percentages indicate retention of SEAP titer and copy number at day 74 relative to day 0 . (d): Boxplots of the data shown in (c). Welch's $t$ tests. WT: $n=23, C M V:: X R C C 6$ : $n=15$, CMV::LIG4: $n=16$. Whiskers showing $\min / \max$. 


\section{Supplemental Figures}
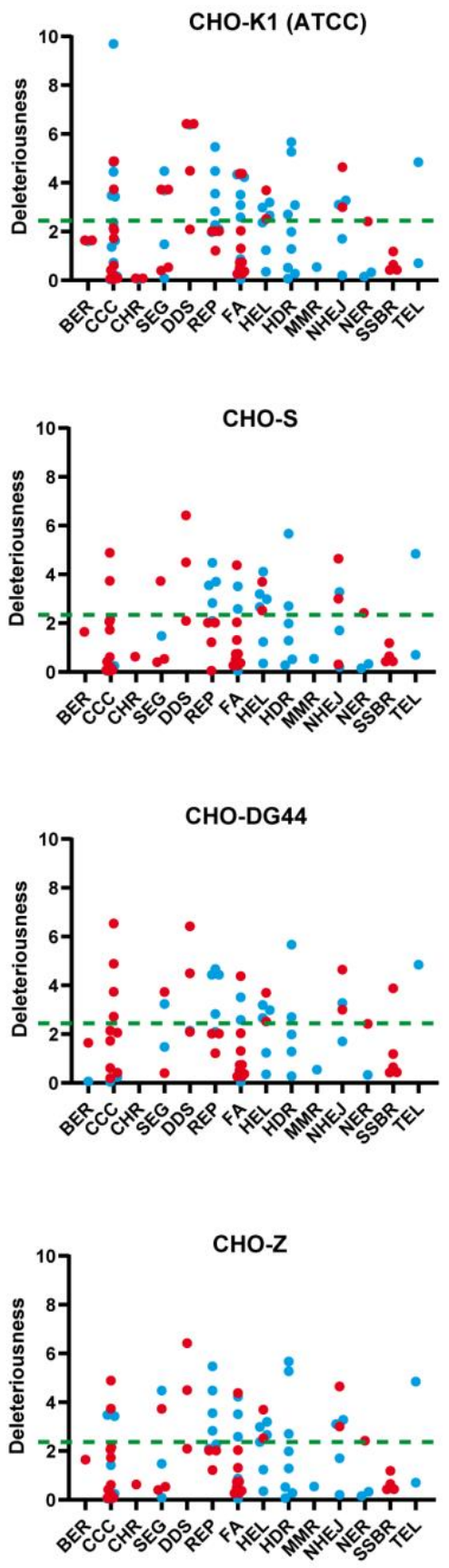
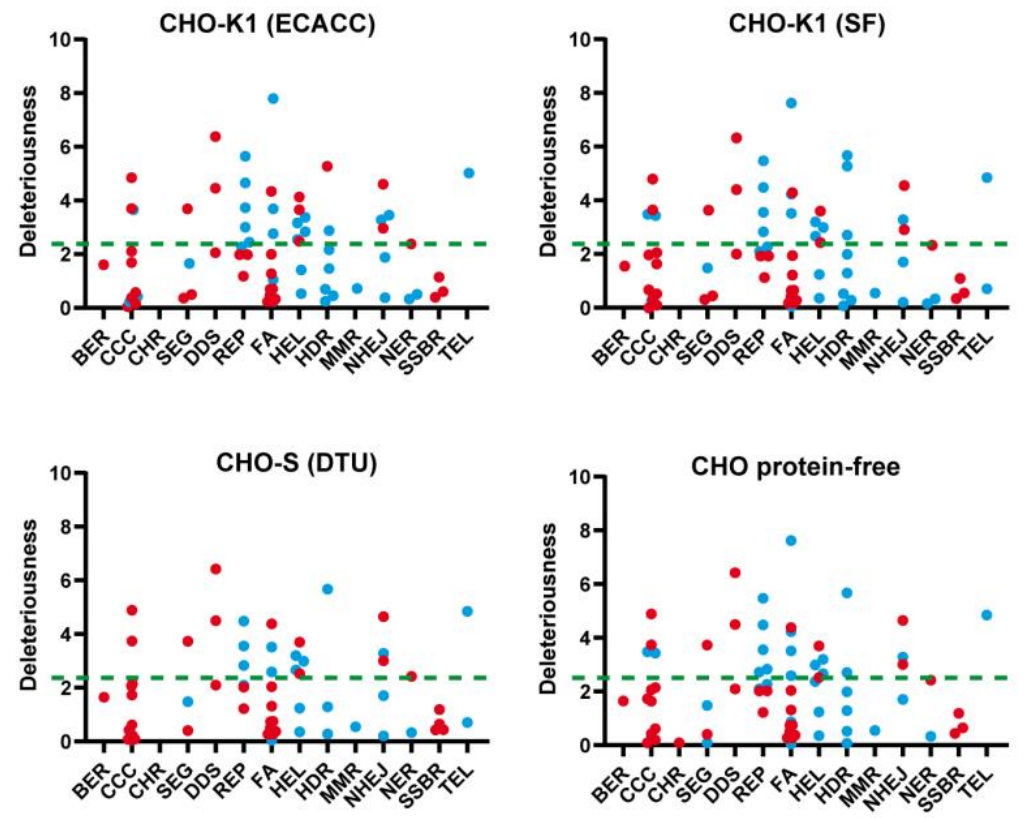

CHO-DXB11
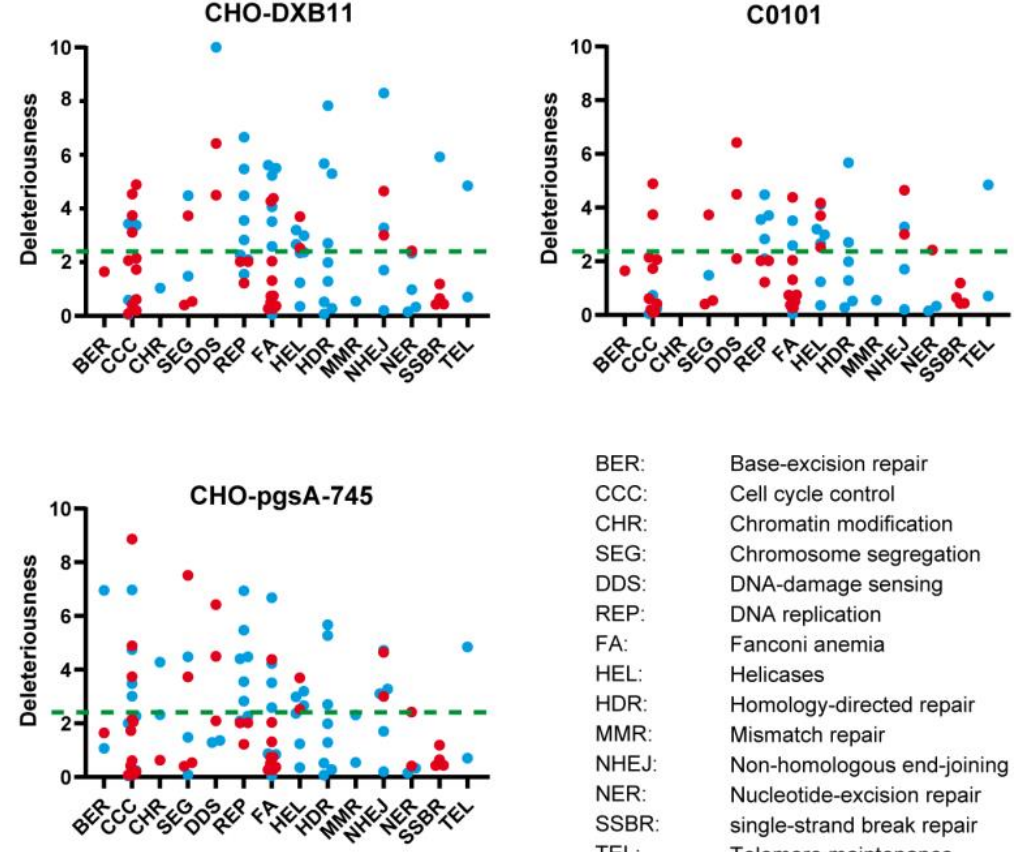

$\begin{array}{ll}\text { BER: } & \text { Base-excision repair } \\ \text { CCC: } & \text { Cell cycle control } \\ \text { CHR: } & \text { Chromatin modification } \\ \text { SEG: } & \text { Chromosome segregation } \\ \text { DDS: } & \text { DNA-damage sensing } \\ \text { REP: } & \text { DNA replication } \\ \text { FA: } & \text { Fanconi anemia } \\ \text { HEL: } & \text { Helicases } \\ \text { HDR: } & \text { Homology-directed repair } \\ \text { MMR: } & \text { Mismatch repair } \\ \text { NHEJ: } & \text { Non-homologous end-joining } \\ \text { NER: } & \text { Nucleotide-excision repair } \\ \text { SSBR: } & \text { single-strand break repair } \\ \text { TEL: } & \text { Telomere maintenance }\end{array}$

Suppl. Fig. 1: Mutations in genes relevant to genome stability in various $\mathrm{CHO}$ cell lines.

Predicted deleteriousness (Negative PROVEAN score) of mutations (SNPs and Indels) in genes related to genome stability (see legend at bottom-right) in a panel of commonly used $\mathrm{CHO}$ cell lines. Blue dots indicate heterozygous mutations, red dots indicate loss of heterozygosity. Green dotted line indicates significance threshold [51]. 


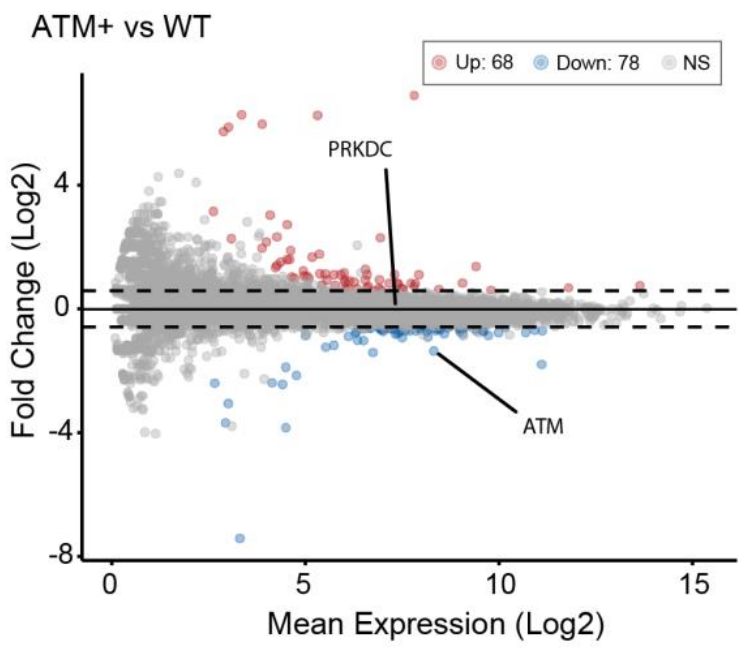

ATM+ PRKDC+ vs WT

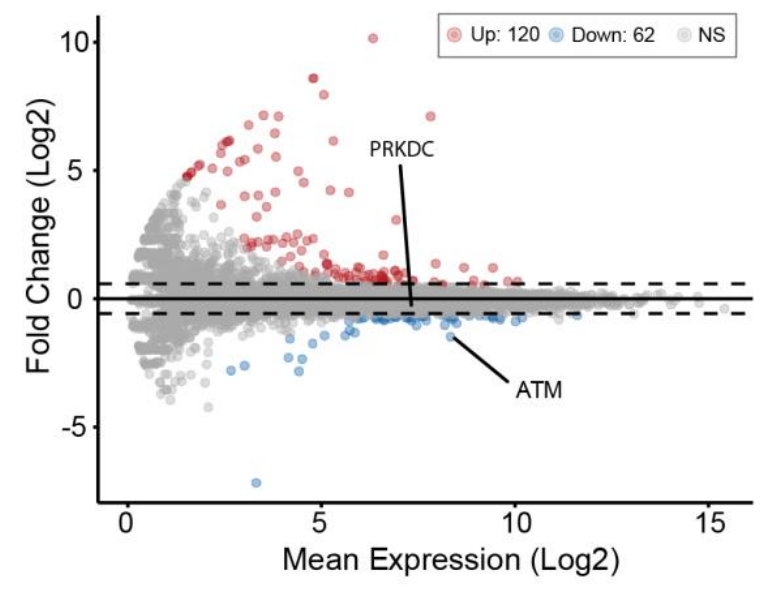

ATM+ PRKDC+ vs ATM+

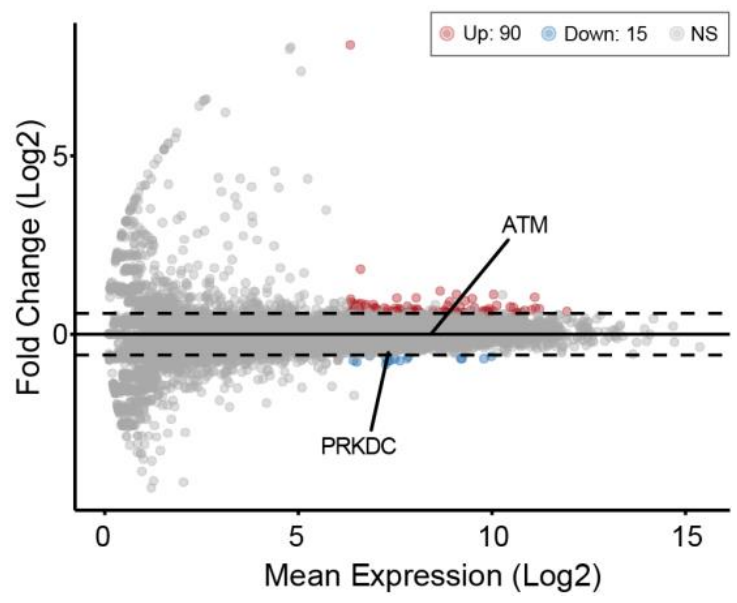

Suppl. Fig. 2: Transcriptomic analysis of CHO-K1 cell lines after SNP reversals. Top: Transcript abundance (x-axis) in CHO-K1 ATM+. Transcript fold-change (y-axis) relative to CHO-K1 WT. Middle: Transcript abundance (x-axis) in CHO-K1 ATM+ PRKDC+. Transcript fold-change (y-axis) relative to 
bioRxiv preprint doi: https://doi.org/10.1101/2021.01.07.425558; this version posted January 7, 2021. The copyright holder for this preprint (which was not certified by peer review) is the author/funder. All rights reserved. No reuse allowed without permission.

CHO-K1 WT. Bottom: Transcript abundance (x-axis) in CHO-K1 ATM+ PRKDC+. Transcript foldchange (y-axis) relative to CHO-K1 ATM+. Significantly up-/downregulated genes highlighted in red/blue. 


\section{Materials \& Methods}

\section{Sequence analysis and statistics}

Whole-genome sequencing data of $11 \mathrm{CHO}$ cell lines [4, 5] (Table 1) was downloaded from Genbank (https://www.ncbi.nlm.nih.gov/sra), together with the Chinese hamster genome [5]. Raw sequencing reads were pre-processed using FastQC [75] for quality control and Trimmomatic [76] to remove lowquality base pairs and adapters. For mapping, the RefSeq $\mathrm{CHO}$ genome assembly GCF_000223151.1 was used. Transcript sequences of DNA repair genes [50] extracted from the reference genome assembly are known to have a low proportion of mismatches compared to the higher quality RefSeq transcripts. Thus, to ensure the reference genome has the correct sequences of DNA repair genes, RefSeq transcript sequences of DNA repair genes were merged into one scaffold separated by a 500 letter $\mathrm{N}$ gap. In cases of multiple isoforms, the transcript with the longest coding sequence was selected. Genomic coding regions of corresponding DNA repair genes were masked. Then the sequencing reads were mapped against the new reference genome using BWA [77]. Non-synonymous SNPs and InDels (including heterozygosity) were identified using the gatk3.5 software package [78] using standard parameters and annotated using SnpEff [79]. SnpSift [80] was used to filter genes with ontologies related to DNA repair [50]. Deleteriousness of mutations was predicted based on the PROVEAN score [51]. Protein-protein interaction networks were generated with STRING [81]. RNA was extracted in from triplicate flasks (RNeasy, Qiagen) and stored at $-80^{\circ} \mathrm{C}$ before sequencing. RNA-sequencing data quality was assessed using FastQC [75]. Adapter sequences and low-quality bases were trimmed using Trimmomatic [76]. Reads were then quasimapped to the CHO-K1 genome [4, 5] and quantified with Salmon [82] using default parameters. Raw gene expression data were then normalized and analyzed for differential expression using DESeq2 [83]. After Benjamini-Hochberg FDR correction, genes with adjusted p-values less than 0.05 and fold changes greater than $\log _{2}(1.5)$ were considered differentially expressed. Statistical tests and sample sizes are indicated in the figure legends. ${ }^{* *} p<0.001,{ }^{* \star} p<0.01,{ }^{*} p<0.05, \# p<0.1$, ns not significant. Tests were carried out in Prism (GraphPad) or R (The R Project for Statistical Computing).

\section{Cell culture and cell line generation}

CHO-K1 cells (ATCC: CCL-61) and CHO-SEAP cells [61] were cultured in F-12K medium (Gibco), or Iscove's Modified Dulbecco's Medium (IMDM), respectively, supplemented with $10 \%(\mathrm{v} / \mathrm{v})$ fetal bovine 
serum (FBS, Corning) and $1 \%(\mathrm{v} / \mathrm{v})$ penicillin/streptomycin (Gibco) at $37^{\circ} \mathrm{C}$ under an atmosphere of $5 \% \mathrm{CO}_{2}$. Cells were passaged every $2-3$ days. CHO-K1 EJ5-GFP and CHO-SEAP EJ5-GFP were generated by transfecting CHO-K1 cells, or CHO-SEAP cell respectively, with a Xhol-linearized EJ5GFP plasmid (Addgene \#44026) and subsequent combined selection with puromycin $(7 \mu \mathrm{g} / \mathrm{mL}$ ) and hygromycin $(300 \mu \mathrm{g} / \mathrm{mL})$. After two weeks of antibiotic selection, clonal populations were generated by seeding cells in limiting dilution on 96-well plates and visually selecting clonal colonies. EJ5-GFP insertion was verified by PCR (OneTaq, New England Biolabs). CHO-K1 ATM+ was generated by transfecting a clonal population of CHO-K1 EJ5-GFP with a Cas9:tracrRNA:sgRNA ribonucleoprotein particle (Integrated DNA Technologies), targeting R2830H in ATM (Gene ID: 100754226), and a homology donor oligo encoding the corrected sequence, following standard protocols (Integrated DNA Technologies). Clonal populations were generated through limiting dilution, and the R2830H site was screened by PCR for the presence of a Taql site in the corrected locus and verified by Sanger sequencing (Eton Biosciences). Sanger sequencing data was deconvoluted using the ICE Analysis Tool (Synthego). CHO-K1 ATM+ PRKDC+ was generated by transfecting a clonal population of CHOK1 ATM+ with a Cas9:tracrRMA:sgRNA ribonucleoprotein particle, targeting D1641N in PRKDC (Gene ID: 100770748), and a homology donor oligo encoding the corrected sequence. Clonal populations were generated through limiting dilution, and the PRKDC D1641N site was screened by PCR for the presence of a BamHI site in the corrected locus and verified by Sanger sequencing. CHO-SEAP CMV::XRCC6 and CHO-SEAP CMV::LIG4 were generated by transfection of CHO-SEAP EJ5-GFP with the corresponding expression plasmids and maintained in IMDM media. At 24 hours post transfection, single cell clones were generated by serial dilution in 96-well plates and maintained in growth media with $200 \mu \mathrm{g} / \mathrm{mL}$ Zeocin and $5 \mu \mathrm{M}$ methotrexate (MTX, EMD Millipore). CHO-SEAP CMV::XRCC6 ATM+ PRKDC+ was generated analogously to CHO-K1 ATM+ PRKDC+. Transfections with ribonucleoprotein particles were carried out using a Neon electroporation system (ThermoFisher) (12-well format). Transfection of DSB repair gene plasmids was carried out using a Nucleofector Kit T (Lonza) with $6 \times 10^{6}$ cells transfected and $6 \mu \mathrm{g}$ plasmid. All cells were maintained under combined puromycin/hygromycin selection throughout the experiments to avoid loss of the EJ5-GFP insertion. Double-strand-breaks were induced using bleomycin sulfate (Sigma-Aldrich). ATM was inhibited with KU-60019 (Selleckchem). 


\section{Cloning of Chinese hamster genes}

Chinese hamster (Cricetulus griseus) tissue (lung, liver) was a gift from George Yerganian. RNA extraction (RNeasy, Qiagen) and total cDNA synthesis (SuperScriptIII, Invitrogen) were carried out using standard protocols. cDNA was purified and concentrated using ethanol precipitation, and $1 \mu \mathrm{L}$ purified total cDNA (100-200 ng) was used to amplify target genes through high-fidelity PCR (Q5, New England Biolabs). A vector backbone fragment was obtained by PCR amplification from plasmid pcDNA3.1/zeo(+) (ThermoFisher). Plasmids expressing DSB repair genes were constructed via Gibson assembly of gene fragment(s) and the vector fragment following the manufacturer's instructions (New England Biolabs).

\section{EJ5-GFP flow cytometry assays}

The DSB-inducer plasmid was constructed by ligation of two sgRNAs, targeting the EJ5-GFP cassette, into pX333 (Addgene \#64073), and subsequent Drdl/Kpnl-subcloning of the entire dual sgRNA expression cassette into pSpCas9(BB)-2A-miRFP670 (Addgene \#91854). To run the EJ5GFP assay, cells were transfected with $1 \mu \mathrm{g}$ of this plasmid (Lipofectamine LTX, Invitrogen; 12-well format). After $30 \mathrm{~h}$ cells were trypsinized, resuspended in $250 \mu \mathrm{L}$ DPBS (Gibco), and analyzed on a Canto II flow cytometer (BD Biosciences). Untransfected cells served as negative control to define proper gates in the APC and FITC channels for miRFP and GFP expression, respectively. DSB-repair negative cells were identified through Boolean gating, as shown in Fig. 3b. Flow cytometry data was analyzed in FlowJo (BD Biosciences) and Prism (GraphPad).

Immunofluorescence, comet assays and microscopy

Cells were seeded on chambered slides (Nunc, ThermoFisher) and, after attachment, either treated with 0.5 Gy X-ray radiation (X-RSD 320, Precision X-ray), or incubated with $10 \mu \mathrm{g} / \mathrm{mL}$ bleomycin sulfate (Sigma-Aldrich) for $12 \mathrm{~h}$. After the indicated recovery time, cells were fixated in $4 \%$ paraformaldehyde (ThermoFisher) for $10 \mathrm{~min}$, washed in PBS (Gibco) for $2 \mathrm{~min}$, and permeabilized with $0.5 \%$ Triton-X (Amresco) for 5 min, followed by washing for 5 min in PBS. After blocking with $5 \%$ goat-serum (MilliporeSigma) for $1 \mathrm{~h}$, cells were incubated in anti-pH2AX antibody (Cell Signaling Technology, Rabbit \#9718) at 1:1000 dilution for $1 \mathrm{~h}$, washed three times in PBS-T (=0.1\% Triton-X in PBS) for 5 min, and incubated with DyLight 488 goat-anti-rabbit (ThermoFisher) for $1 \mathrm{~h}$ in the dark. After three washes in PBS-T for 5 min, cells were mounted in anti-fade mounting medium, containing 
DAPI (Vectashield Vibrance, Vector Laboratories). Samples were analyzed on a SP8 confocal microscope (Leica) with identical settings for gain and offset for each sample. Images were analyzed using Image $(\mathrm{NIH})$, following standard protocols for foci enumeration (https://microscopy.duke.edu/guides/count-nuclear-foci-ImageJ). Comet assays were carried out following the manufacturer's protocol (Abcam), with $45 \mathrm{~min}$ electrophoresis at $1 \mathrm{~V} / \mathrm{cm}$ in TBE-buffer. Nuclei were stained with Vista DNA Green (Abcam). Slides were analyzed on an Axio Imager 2 (Zeiss) and processed using the OpenComet plug-in (www.cometbio.org/index.html) for ImageJ $(\mathrm{NIH})$.

\section{Long-term culture and SEAP quantification}

For long-term culture, selected cell lines were seeded at $1 \times 10^{5}$ cells $/ \mathrm{mL}$ and subcultured for four passages with $5 \mu \mathrm{M}$ MTX in 24-well plates. Then, cells were subcultured every three or four days for 74 days without MTX selection. Cell lines expressing XRCC6 and LIG4 were continuously maintained in media with $200 \mu \mathrm{g} / \mathrm{mL}$ Zeocin. Cell lines at Day 0 and Day 74 were seeded at $1 \times 10^{5} \mathrm{cells} / \mathrm{mL}$ in 6well plates containing $3 \mathrm{~mL}$ growth media per well without MTX. When the cell density reached $\sim 80 \%$ confluency, culture supernatant samples were collected for SEAP quantification (PhosphaLight, AppliedBiosystems). Alkaline phosphatase from human placenta (Sigma-Aldrich) was assayed and used as a standard. Gene copy number was determined by Real-Time PCR using TaqMan Fast Advanced Master Mix (Thermo Fisher) performed on a 7500 fast system (Applied Biosystems) according to the manufacturer's protocol. PCR primers and TaqMan probes were designed and synthesized by IDT (Integrated DNA Technologies). Genomic DNA was extracted from Day 0 and Day 74 cell samples (DNeasy, Qiagen). The diluted genomic DNA of one CHO-SEAP clone (400 ng, $200 \mathrm{ng}, 100 \mathrm{ng}, 50 \mathrm{ng}, 25 \mathrm{ng}, 0 \mathrm{ng}$ ) was used to make a standard curve. Relative SEAP gene copy number in each cell sample was quantified in duplicate using $100 \mathrm{ng}$ genomic DNA as a template with $\beta$-Actin as a reference.

\section{Karyotype analysis}

Metaphase spreads were prepared as previously described [37]. Samples were labeled with multicolor DNA fluorescence in situ hybridization (FISH) probes (12XCHamster mFISH probe kit, MetaSystems) for spectral karyotyping as previously described [84]. For karyotypic analyses, the most abundant karyotype across samples was defined as the representative ("main") karyotype, and 
deviations from this karyotype were scored as a numerical alteration (whole-chromosomal aneuploidy) and/or structural alteration (inter-chromosomal rearrangement, visible deletion). Structurally aberrant karyotypes (Fig. 4d) were defined as karyotypes showing at least one structural deviation from the representative karyotype.

\section{DNA oligos}

Primers

\begin{tabular}{|c|c|}
\hline EJ5-GFP Insertion & $\begin{array}{l}\text { F: AGCCTCTGTTCCACATACACT } \\
\text { R: CCAGCCACCACCTTCTGATA }\end{array}$ \\
\hline ATM R2830H & $\begin{array}{l}\text { F: AGAGGTGTCCAGGCCAAGTT } \\
\text { R: GAGCTAACAATCAGCACGAACA }\end{array}$ \\
\hline PRKDC D1641N & $\begin{array}{l}\text { F: AGAACCAGTTGCTGTAGTCTTGT } \\
\text { R: CCTGTGTGGTGATGGTGCATA }\end{array}$ \\
\hline Cloning of C.gri. XRCC6 & $\begin{array}{l}\text { F: TTATGCTAGCCCTTCTGTCCCTTTGGCTCG } \\
\text { R: TTATGAATTCTAAGTAGGTGGTCTGGCTGC }\end{array}$ \\
\hline Cloning of C.gri. LIG4 & $\begin{array}{l}\text { F: GGAGACCCAAGCTGGCTAGCTTGCTTCTATGGCTACCTCA } \\
\text { R: GCCTGGATTCTGCACTATAT }\end{array}$ \\
\hline $\begin{array}{l}\text { Subcloning of sgRNA } \\
\text { expression locus ( } p \times 333 \text { ) }\end{array}$ & $\begin{array}{l}\text { F: ACGACCTACACCGAACTGAG } \\
\text { R: AGGTCATGTACTGGGCACAA }\end{array}$ \\
\hline SEAP copy number & $\begin{array}{l}\text { F: TCGTATTTCATGTCTCCAGGC } \\
\text { R: AGAATCTGGTGCAGGAATGG } \\
\text { Probe: 5'-6-FAM-CATGAGATG-ZEN-GGTCACAGACGGGT-3'-AbkFQ }\end{array}$ \\
\hline$\beta$-Actin copy number & $\begin{array}{l}\text { F: ACACCTTCTACAACGAGCTG } \\
\text { R: CCTGAATGGCTACGTACATGG } \\
\text { Probe: 5'-6-FAM-TCTGGGTCA-ZEN-TCTTTTCACGGTTGGC-3'-ABkFQ }\end{array}$ \\
\hline XRCC6 qPCR & $\begin{array}{l}\text { F: ATGGAGTCTGAGCAAGTGGT } \\
\text { R: TGCTTCTTCGGTCCACTCTT }\end{array}$ \\
\hline LIG4 qPCR & $\begin{array}{l}\text { F: AGGCTGAGCGTTCGGAGA } \\
\text { R: CATCCTTGCCTTCTCTTGGT }\end{array}$ \\
\hline GAPDH qPCR & $\begin{array}{l}\text { F: CCTGGAGAAACCTGCCAAGTATGA } \\
\text { R: AGCCCСTCCTTATTCTGGGGG }\end{array}$ \\
\hline
\end{tabular}


All primers were designed using Primer3 [85].

sgRNAs

\begin{tabular}{|l|l|}
\hline Targeting ATM R2830H & AGCCTCTGTTCCACATACACT \\
\hline Targeting PRKDC D1641N & TGGCCAGGCTCTTACAGCTG \\
\hline DSB induction (EJ5-GFP assay) (5' end) & AACAGGGTAATAATTCTACC \\
\hline DSB induction (EJ5-GFP assay) (3' end) & TAACAGGGTAATGGATCCAC \\
\hline
\end{tabular}

ssDNA Oligos

\begin{tabular}{|c|c|}
\hline ATM R2830H homology donor & $\begin{array}{l}\text { GTTTCTCAAACCAAACAGCTGGGTCCAAGAATTTTT } \\
\text { CCATACAAAAATATCGAAAAACTGGTTCAAAGTTTT } \\
\text { GGCAAATAGTCATGAAGGTGTCA }\end{array}$ \\
\hline PRKDC D1641N homology donor & $\begin{array}{l}\text { САTTGCTCCTGCAGAGGAAAGGCAGTGCCTGCAAT } \\
\text { САTTGGATCCTAGCTGTAAGAGCCTGGCCAATGGA } \\
\text { СTCCTGGAGTTAGCCT }\end{array}$ \\
\hline
\end{tabular}




\section{Acknowledgements}

We would like to express our deep gratitude to George Yerganian for sharing primary Chinese hamster tissue. We thank Bjørn Voldborg and Alexandra Hoffmeyer for sharing cell lines and for RNA sequencing services. We would also like to thank Francisco Diaz, Jennifer Santini and Marcy Erb for technical assistance, and Nicole Borth for sharing protocols. We also thank John Ruano-Salguero for revising the manuscript, Jong Youn Baik, and Philip Gordts for constructive feedback, and John Koh and April Kloxin for sharing cell lines. This work was supported by NIGMS (R35 GM119850, NEL), the Novo Nordisk Foundation (NNF10CC1016517, NEL) and NSF (grants 1736123 and 1412365, KHL). Laser-scanning confocal microscopy was supported by NINDS P30 NS047101.

\section{Author Contributions}

PNS, XZ, QH, NKH, PL, KHL, NEL designed research; PNS, XZ, QH, HH, SL, CCK, YH, JCL performed research; PNS, XZ, QH, HH, SL, CCK, YH, JCL, PL, KHL, NEL analyzed data; PNS, XZ, KHL, NEL wrote the paper.

\section{Conflict of Interest}

The authors are listed as inventors on two pending patent applications by the University of Delaware and the University of California, related to observations in this manuscript. 


\section{References}

1. Walsh G (2018) Biopharmaceutical benchmarks 2018. Nature Biotechnology, 24(7):769-776. https://doi.org/10.1038/nbt.3040

2. Bandaranayake AD, Almo SC (2014) Recent advances in mammalian protein production. FEBS Letters, 588(2):253-260. https://doi.org/10.1016/j.febslet.2013.11.035

3. Xu X, Nagarajan H, Lewis NE, Pan S, Cai Z, Liu X, Chen W, Xie M, Wang W, Hammond S, Andersen MR, Neff N, Passarelli B, Koh W, Fan HC, Wang J, Gui Y, Lee KH, Betenbaugh MJ, Quake SR, Famili I, Palsson BO, Wang J (2011) The genomic sequence of the Chinese hamster ovary (CHO)-K1 cell line. Nature Biotechnology, 29(8):735-41. https://doi.org/10.1038/nbt.1932

4. Rupp O, MacDonald ML, Li S, Dhiman H, Polson S, Griep S, Heffner K, Hernandez I, Brinkrolf K, Jadhav V, Samoudi M, Hao H, Kingham B, Goesmann A, Betenbaugh MJ, Lewis NE, Borth N, Lee $\mathrm{KH}$ (2018) A reference genome of the Chinese hamster based on a hybrid assembly strategy. Biotechnology and Bioengineering, 115(8):2087-2100. https://doi.org/10.1002/bit.26722

5. Lewis NE, Liu X, Li Y, Nagarajan H, Yerganian G, O'Brien E, Bordbar A, Roth AM, Rosenbloom J, Bian C, Xie M, Chen W, Li N, Baycin-Hizal D, Latif H, Forster J, Betenbaugh MJ, Famili I, Xu X, Wang J, Palsson BO (2013) Genomic landscapes of Chinese hamster ovary cell lines as revealed by the Cricetulus griseus draft genome. Nature Biotechnology, 31(8):759-65. https://doi.org/10.1038/nbt.2624

6. Yusufi FNK, Lakshmanan M, Ho YS, Loo BLW, Ariyaratne P, Yang Y, Ng SK, Tan TRM, Yeo HC, Lim HL, Ng SW, Hiu AP, Chow CP, Wan C, Chen S, Teo G, Song G, Chin JX, Ruan X, Sung KWK, Hu W-S, Yap MGS, Bardor M, Nagarajan N, Lee D-Y (2017) Mammalian Systems Biotechnology Reveals Global Cellular Adaptations in a Recombinant CHO Cell Line. Cell Systems, 4(5):530-542.e6. https://doi.org/https://doi.org/10.1016/j.cels.2017.04.009

7. Zong Y, Wang Y, Li C, Zhang R, Chen K, Ran Y, Quu J-L, Wang D, Gao C (2017) Precise base editing in rice, wheat and maize with a Cas9- cytidine deaminase fusion. Nature Biotechnology, 35(5):438-440. https://doi.org/10.1038/nbt.3811

8. Hilliard W, MacDonald ML, Lee KH (2020) Chromosome-scale scaffolds for the Chinese hamster reference genome assembly to facilitate the study of the $\mathrm{CHO}$ epigenome. Biotechnology and Bioengineering, 117(8):2331-2339. https://doi.org/10.1002/bit.27432

9. Collins JH, Young EM (2018) Genetic engineering of host organisms for pharmaceutical synthesis. Current Opinion in Biotechnology, 53:191-200. https://doi.org/10.1016/j.copbio.2018.02.001

10. Ronda C, Pedersen LE, Hansen HG, Kallehauge TB, Betenbaugh MJ, Nielsen AT, Kildegaard HF (2014) Accelerating genome editing in CHO cells using CRISPR Cas9 and CRISPy, a web-based target finding tool. Biotechnology and Bioengineering, 111(8):1604-1616. https://doi.org/10.1002/bit.25233

11. Lee JS, Grav LM, Lewis NE, Kildegaard HF (2015) CRISPR/Cas9-mediated genome engineering of $\mathrm{CHO}$ cell factories: Application and perspectives. Biotechnology Journal, 10(7):979-994. https://doi.org/10.1002/biot.201500082

12. Pristovšek N, Nallapareddy S, Grav LM, Hefzi H, Lewis NE, Rugbjerg P, Hansen HG, Lee GM, Andersen MR, Kildegaard HF (2019) Systematic Evaluation of Site-Specific Recombinant Gene Expression for Programmable Mammalian Cell Engineering. ACS Synthetic Biology, 8(4):757-774. https://doi.org/10.1021/acssynbio.8b00453

13. Xiong K, Marquart KF, Cour Karottki KJ la, Li S, Shamie I, Lee JS, Gerling S, Yeo NC, Chavez A, Lee GM, Lewis NE, Kildegaard HF (2019) Reduced apoptosis in Chinese hamster ovary cells via optimized CRISPR interference. Biotechnology and Bioengineering, 116(7):1813-1819. https://doi.org/10.1002/bit.26969

14. Weinguny $M$, Eisenhut $P$, Klanert $G$, Virgolini $N$, Marx N, Jonsson $A$, Ivansson $D$, Lövgren $A$, Borth N (2020) Random epigenetic modulation of $\mathrm{CHO}$ cells by repeated knockdown of DNA methyltransferases increases population diversity and enables sorting of cells with higher production capacities. Biotechnology and bioengineering, https://doi.org/10.1002/bit.27493

15. Kildegaard HF, Baycin-Hizal D, Lewis NE, Betenbaugh MJ (2013) The emerging CHO systems 
biology era: harnessing the 'omics revolution for biotechnology. Current Opinion in Biotechnology, 24(6):1102-7. https://doi.org/10.1016/j.copbio.2013.02.007

16. Stolfa G, Smonskey MT, Boniface R, Hachmann AB, Gulde P, Joshi AD, Pierce AP, Jacobia SJ, Campbell A (2018) CHO-Omics Review: The Impact of Current and Emerging Technologies on Chinese Hamster Ovary Based Bioproduction. Biotechnology Journal, 13(3):1-14. https://doi.org/10.1002/biot.201700227

17. Daniotti JL, Vilcaes A a, Torres Demichelis V, Ruggiero FM, Rodriguez-Walker M (2013) Glycosylation of glycolipids in cancer: basis for development of novel therapeutic approaches. Frontiers in Oncology, 3(December):306. https://doi.org/10.3389/fonc.2013.00306

18. Kim JY, Kim YG, Lee GM (2012) CHO cells in biotechnology for production of recombinant proteins: Current state and further potential. Applied Microbiology and Biotechnology, 93(3):917-930. https://doi.org/10.1007/s00253-011-3758-5

19. Bailey LA, Hatton D, Field R, Dickson AJ (2012) Determination of Chinese hamster ovary cell line stability and recombinant antibody expression during long-term culture. Biotechnology and Bioengineering, 109(8):2093-2103. https://doi.org/10.1002/bit.24485

20. Kim M, O'Callaghan PM, Droms KA, James DC (2011) A mechanistic understanding of production instability in $\mathrm{CHO}$ cell lines expressing recombinant monoclonal antibodies. Biotechnology and Bioengineering, 108(10):2434-2446. https://doi.org/10.1002/bit.23189

21. Chusainow J, Yang YS, Yeo JHM, Ton PC, Asvadi P, Wong NSC, Yap MGS (2009) A study of monoclonal antibody-producing $\mathrm{CHO}$ cell lines: What makes a stable high producer? Biotechnology and Bioengineering, 102(4):1182-1196. https://doi.org/10.1002/bit.22158

22. Veith N, Ziehr H, MacLeod RAF, Reamon-Buettner SM (2016) Mechanisms underlying epigenetic and transcriptional heterogeneity in Chinese hamster ovary $(\mathrm{CHO})$ cell lines. BMC Biotechnology, 16(1):1-16. https://doi.org/10.1186/s12896-016-0238-0

23. Moritz B, Woltering L, Becker PB, Göpfert U (2016) High levels of histone H3 acetylation at the $\mathrm{CMV}$ promoter are predictive of stable expression in Chinese hamster ovary cells. Biotechnology Progress, 32(3):776-786. https://doi.org/10.1002/btpr.2271

24. Mutskov V, Felsenfeld $G$ (2004) Silencing of transgene transcription precedes methylation of promoter DNA and histone H3 lysine 9. EMBO Journal, 23(1):138-149. https://doi.org/10.1038/sj.emboj. 7600013

25. Paredes V, Park JS, Jeong Y, Yoon J, Baek K (2013) Unstable expression of recombinant antibody during long-term culture of $\mathrm{CHO}$ cells is accompanied by histone $\mathrm{H} 3$ hypoacetylation. Biotechnology Letters, 35(7):987-993. https://doi.org/10.1007/s10529-013-1168-8

26. Yang Y, Mariati, Chusainow J, Yap MGS (2010) DNA methylation contributes to loss in productivity of monoclonal antibody-producing $\mathrm{CHO}$ cell lines. Journal of Biotechnology, 147(34):180-185. https://doi.org/10.1016/j.jbiotec.2010.04.004

27. Fann CH, Guirgis F, Chen G, Lao MS, Piret JM (2000) Limitations to the amplification and stability of human tissue-type plasminogen activator expression by Chinese hamster ovary cells. Biotechnology and Bioengineering, 69(2):204-212. https://doi.org/10.1002/(SICl)10970290(20000720)69:2<204::AID-BIT9>3.0.CO;2-Z

28. Kim SJ, Kim NS, Ryu CJ, Hong HJ, Lee GM (1998) Characterization of Chimeric Antibody Producing $\mathrm{CHO}$ Cells in the Course of Dihydrofolate Reductase-Mediated Gene Amplification and Their Stability in the Absence of Selective Pressure. Biotechnology and Bioengineering, 58(1)

29. Barnes LM, Bentley CM, Dickson AJ (2003) Stability of protein production from recombinant mammalian cells. Biotechnology and Bioengineering, 81(6):631-639. https://doi.org/10.1002/bit.10517

30. Beckmann TF, Krämer $\mathrm{O}$, Klausing $\mathrm{S}$, Heinrich $\mathrm{C}$, Thüte $\mathrm{T}$, Büntemeyer $\mathrm{H}$, Hoffrogge $\mathrm{R}$, Noll T (2012) Effects of high passage cultivation on CHO cells: A global analysis. Applied Microbiology and Biotechnology, 94(3):659-671. https://doi.org/10.1007/s00253-011-3806-1

31. Hammill L, Welles J, Carson GR (2000) The gel microdrop secretion assay: Identification of a low productivity subpopulation arising during the production of human antibody in $\mathrm{CHO}$ cells. Cytotechnology, 34(1-2):27-37. https://doi.org/10.1023/A:1008186113245 
32. Baik JY, Lee $\mathrm{KH}$ (2016) A framework to quantify karyotype variation associated with $\mathrm{CHO}$ production instability. Biotechnology and Bioengineering, :1-24. https://doi.org/10.1002/bit.26231

33. Dahodwala H, Lee KH (2019) The fickle CHO: a review of the causes, implications, and potential alleviation of the $\mathrm{CHO}$ cell line instability problem. Current Opinion in Biotechnology, 60(August 2018):128-137. https://doi.org/10.1016/j.copbio.2019.01.011

34. Khanna KK, Jackson SP (2001) DNA double-strand breaks: signaling, repair and the cancer connection. Nature Genetics, 27(3):247-54. https://doi.org/10.1038/85798

35. Worton RG, Ho CC, Duff C (1977) Chromosome stability in CHO cells. Somatic cell genetics, 3(1):27-45. https://doi.org/10.1007/BF01550985

36. Deaven LL, Petersen DF (1973) The chromosomes of CHO, an aneuploid Chinese hamster cell line: G-band, C-band, and autoradiographic analyses. Chromosoma, 41(2):129-144. https://doi.org/10.1007/BF00319690

37. Vcelar S, Jadhav V, Melcher M, Auer N, Hrdina A, Sagmeister R, Heffner K, Puklowski A, Betenbaugh M, Wenger T, Leisch F, Baumann M, Borth N (2018) Karyotype variation of CHO host cell lines over time in culture characterized by chromosome counting and chromosome painting. Biotechnology and Bioengineering, 115(1):165-173. https://doi.org/10.1002/bit.26453

38. Wurm F, Wurm M (2017) Cloning of CHO Cells, Productivity and Genetic Stability-A Discussion. Processes, 5(2):20. https://doi.org/10.3390/pr5020020

39. Feichtinger J, Hernández I, Fischer C, Hanscho M, Auer N, Hackl M, Jadhav V, Baumann M, Krempl PM, Schmidl C, Farlik M, Schuster M, Merkel A, Sommer A, Heath S, Rico D, Bock C, Thallinger GG, Borth N (2016) Comprehensive genome and epigenome characterization of $\mathrm{CHO}$ cells in response to evolutionary pressures and over time. Biotechnology and Bioengineering, 113(10):2241-2253. https://doi.org/10.1002/bit.25990

40. Richardson C, Moynahan ME, Jasin M (1998) Double-strand break repair by interchromosomal recombination: Suppression of chromosomal translocations. Genes and Development, 12(24):38313842. https://doi.org/10.1101/gad.12.24.3831

41. Gent DC Van, Hoeijmakers JHJ, Kanaar R (2001) Chromosomal stability and the DNA doublestranded break connection. Nature Reviews Genetics, 2(3):196-206. https://doi.org/10.1038/35056049

42. Kaas CS, Kristensen C, Betenbaugh MJ, Andersen MR (2015) Sequencing the CHO DXB11 genome reveals regional variations in genomic stability and haploidy. BMC Genomics, 16(1):1-9. https://doi.org/10.1186/s12864-015-1391-x

43. Lee JS, Kallehauge TB, Pedersen LE, Kildegaard HF (2015) Site-specific integration in CHO cells mediated by CRISPR/Cas9 and homology-directed DNA repair pathway. Scientific Reports, :1-11. https://doi.org/10.1038/srep08572

44. Lee JS, Park JH, Ha TK, Samoudi M, Lewis NE, Palsson BO, Kildegaard HF, Lee GM (2018) Revealing Key Determinants of Clonal Variation in Transgene Expression in Recombinant CHO Cells Using Targeted Genome Editing. ACS Synthetic Biology, 7(12):2867-2878. https://doi.org/10.1021/acssynbio.8b00290

45. Gaidukov L, Wroblewska L, Teague B, Nelson T, Zhang X, Liu Y, Jagtap K, Mamo S, Allen Tseng W, Lowe A, Das J, Bandara K, Baijuraj S, Summers NM, Lu TK, Zhang L, Weiss R (2018) A multilanding pad DNA integration platform for mammalian cell engineering. Nucleic Acids Research, 46(8):4072-4086. https://doi.org/10.1093/nar/gky216

46. Lee KH, Onitsuka M, Honda K, Ohtake H, Omasa T (2013) Rapid construction of transgeneamplified $\mathrm{CHO}$ cell lines by cell cycle checkpoint engineering. Applied Microbiology and Biotechnology, 97(13):5731-5741. https://doi.org/10.1007/s00253-013-4923-9

47. Matsuyama R, Yamano N, Kawamura N, Omasa T (2017) Lengthening of high-yield production levels of monoclonal antibody-producing Chinese hamster ovary cells by downregulation of breast cancer 1. Journal of Bioscience and Bioengineering, 123(3):382-389. https://doi.org/10.1016/j.jbiosc.2016.09.006

48. Rogakou EP, Boon C, Redon C, Bonner WM (1999) Megabase chromatin domains involved in DNA double-strand breaks in vivo. Journal of Cell Biology, 146(5):905-915. 
https://doi.org/10.1083/jcb.146.5.905

49. Scarpato R, Castagna S, Aliotta R, Azzarà A, Ghetti F, Filomeni E, Giovannini C, Pirillo C, Testi S, Lombardi S, Tomei A (2013) Kinetics of nuclear phosphorylation ( $\mathrm{Y}-\mathrm{H} 2 \mathrm{AX})$ in human lymphocytes treated in vitro with UVB, bleomycin and mitomycin C. Mutagenesis, 28(4):465-473. https://doi.org/10.1093/mutage/get024

50. Wood RD, Mitchell M, Lindahl T (2005) Human DNA repair genes, 2005. Mutation Research Fundamental and Molecular Mechanisms of Mutagenesis, 577(1-2 SPEC. ISS.):275-283. https://doi.org/10.1016/j.mrfmmm.2005.03.007

51. Choi Y, Sims GE, Murphy S, Miller JR, Chan AP (2012) Predicting the Functional Effect of Amino Acid Substitutions and Indels. PLoS ONE, 7(10)https://doi.org/10.1371/journal.pone.0046688

52. Shiloh Y, Ziv $Y$ (2013) The ATM protein kinase: regulating the cellular response to genotoxic stress, and more. Nature Reviews. Molecular Cell Biology, 14(4):197-210. https://doi.org/10.1038/nrm3546

53. Bakkenist CJ, Kastan MB (2003) DNA damage activates ATM through intermolecular autophosphorylation and dimer dissociation. Nature, 421(6922):499-506. https://doi.org/10.1038/nature01368

54. Shiloh Y (2006) The ATM-mediated DNA-damage response: taking shape. Trends in Biochemical Sciences, 31(7):402-410. https://doi.org/10.1016/j.tibs.2006.05.004

55. Jensen RB, Rothenberg E (2020) Preserving genome integrity in human cells via DNA doublestrand break repair. Molecular Biology of the Cell, 31:859-865. https://doi.org/10.1091/mbc.E18-100668

56. Goodarzi AA, Jeggo PA (2013) The Repair and Signaling Responses to DNA Double-Strand Breaks. Advances in Genetics, 82https://doi.org/10.1016/B978-0-12-407676-1.00001-9

57. Scully R, Panday A, Elango R, Willis NA (2019) DNA double-strand break repair-pathway choice in somatic mammalian cells. Nature Reviews Molecular Cell Biology, 20(11):698-714. https://doi.org/10.1038/s41580-019-0152-0

58. Bennardo N, Cheng A, Huang N, Stark JM (2008) Alternative-NHEJ is a mechanistically distinct pathway of mammalian chromosome break repair. PLoS Genetics, 4(6)https://doi.org/10.1371/journal.pgen.1000110

59. Paull TT (2015) Mechanisms of ATM Activation. Annual Review of Biochemistry, 84(1):711-738. https://doi.org/10.1146/annurev-biochem-060614-034335

60. Arentsen HC, Falke J, Høgset A, Oosterwijk E, Alfred Witjes J (2014) The effect of photochemical internalization of bleomycin in the treatment of urothelial carcinoma of the bladder: An in vitro study. Urologic Oncology: Seminars and Original Investigations, 32(1):49.e1-49.e6. https://doi.org/10.1016/j.urolonc.2013.07.005

61. Hayduk EJ, Lee KH (2005) Cytochalasin D can improve heterologous protein productivity in adherent Chinese hamster ovary cells. Biotechnology and Bioengineering, 90(3):354-364. https://doi.org/10.1002/bit.20438

62. Goth-Goldstein R (1980) Inability of Chinese Hamster Ovary Cells to Excise O6-Alkylguanine. Cancer Research, 40(7):2623-2624.

63. Shen MR, Zdzienicka MZ, Mohrenweiser H, Thompson LH, Thelen MP (1998) Mutations in hamster single-strand break repair gene XRCC1 causing defective DNA repair. Nucleic Acids Research, 26(4):1032-1037.

64. Jeggo PA, Holliday R (1986) Azacytidine-induced reactivation of a DNA repair gene in Chinese hamster ovary cells. Molecular and Cellular Biology, 6(8):2944-2949. https://doi.org/10.1128/mcb.6.8.2944

65. Berger A, Fourn V Le, Masternak J, Regamey A, Bodenmann I, Girod PA, Mermod N (2020) Overexpression of transcription factor Foxa1 and target genes remediate therapeutic protein production bottlenecks in Chinese hamster ovary cells. Biotechnology and Bioengineering, 117(4):1101-1116. https://doi.org/10.1002/bit.27274

66. Nguyen LN, Baumann M, Dhiman H, Marx N, Schmieder V, Hussein M, Eisenhut P, Hernandez I, 
Koehn J, Borth N (2019) Novel Promoters Derived from Chinese Hamster Ovary Cells via In Silico and In Vitro Analysis. Biotechnology Journal, 14(11)https://doi.org/10.1002/biot.201900125

67. Bosshard S, Duroy PO, Mermod N (2019) A role for alternative end-joining factors in homologous recombination and genome editing in Chinese hamster ovary cells. DNA Repair, 82(August):102691. https://doi.org/10.1016/j.dnarep.2019.102691

68. Brunette GJ, Jamalruddin MA, Baldock RA, Clark NL, Bernstein KA (2019) Evolution-based screening enables genome-wide prioritization and discovery of DNA repair genes. Proceedings of the National Academy of Sciences, 116(39):201906559. https://doi.org/10.1073/pnas.1906559116

69. Riballo E, Kühne M, Rief N, Doherty A, Smith GCM, Recio MJ, Reis C, Dahm K, Fricke A, Krempler A, Parker AR, Jackson SP, Gennery A, Jeggo PA, Löbrich M (2004) A pathway of doublestrand break rejoining dependent upon ATM, Artemis, and proteins locating to ??-H2AX foci. Molecular Cell, 16(5):715-724. https://doi.org/10.1016/j.molcel.2004.10.029

70. Lim D, Kim S, Xu B, Maser RS (2000) ATM phosphorylates p95/nbs1 in an S-phase checkpoint pathway. Nature, 404(April):613-617.

71. Jackson SP (2002) Sensing and repairing DNA double-strand breaks. Carcinogenesis, 23(5):687696. https://doi.org/10.1093/carcin/23.5.687

72. Acid M, Pilla M, Perachon S, Sautel Ë, Mann Â, Wermuth CG, Garrido F, Schwartz J, Everitt BJ, Sokoloff P, Dyck E Van, Stasiak AZ, Stasiak A, West SC (1999) Binding of double-strand breaks in DNA by human Rad52 protein. Nature, 401(September):371-375.

73. Choi S, Gamper AM, White JS, Bakkenist CJ (2010) Inhibition of ATM kinase activity does not phenocopy ATM protein disruption: Implications for the clinical utility of ATM kinase inhibitors. Cell Cycle, 9(20):4052-4057. https://doi.org/10.4161/cc.9.20.13471

74. Li G, Nelsen C, Hendrickson EA (2002) Ku86 is essential in human somatic cells. Proceedings of the National Academy of Sciences of the United States of America, 99(2):832-837. https://doi.org/10.1073/pnas.022649699

75. Andrews S (2010) fastQC: A quality control tool for high throughput sequence data. https://www.bioinformatics.babraham.ac.uk/projects/fastqc/

76. Bolger AM, Lohse M, Usadel B (2014) Trimmomatic: A flexible trimmer for Illumina sequence data. Bioinformatics, 30(15):2114-2120. https://doi.org/10.1093/bioinformatics/btu170

77. Li H, Durbin R (2009) Fast and accurate short read alignment with Burrows-Wheeler transform. Bioinformatics, 25(14):1754-1760. https://doi.org/10.1093/bioinformatics/btp324

78. McKenna A, Hanna M, Banks E, DePristo M (2010) The Genome Analysis Toolkit: A MapReduce framework for analyzing next-generation DNA sequencing data. Genome Research, 20(1):1297-303. https://doi.org/10.1101/gr.107524.110.20

79. Cingolani P, Platts A, Wang LL, Lu X (2012) A program for annotating and predicting the effects of single nucleotide polymorphisms, SnpEff: SNPs in the genome of Drosophila melanogaster strain w1118; iso-2; iso-3. Fly, 6(2):1-13. https://doi.org/10.4161/fly.19695

80. Cingolani P, Patel VM, Coon M, Nguyen T, Land SJ, Ruden DM, Lu X (2012) Using Drosophila melanogaster as a model for genotoxic chemical mutational studies with a new program, SnpSift. Frontiers in Genetics, 3(MAR):1-9. https://doi.org/10.3389/fgene.2012.00035

81. Szklarczyk D, Franceschini A, Wyder S, Forslund K, Heller D, Huerta-Cepas J, Simonovic M, Roth A, Santos A, Tsafou KP, Kuhn M, Bork P, Jensen LJ, Mering C von (2015) STRING v10: proteinprotein interaction networks, integrated over the tree of life. Nucleic Acid Research, 43(Database issue):D447-52. https://doi.org/10.1093/nar/gku1003

82. Patro R, Duggal G, Love MI, Irizarry RA, Kingsford C (2017) Salmon provides fast and bias-aware quantification of transcript expression. Nature Methods, 14(4):417-419. https://doi.org/10.1038/nmeth.4197

83. Love M, Anders S, Huber W (2014) Differential analysis of count data - the DESeq2 package. Genome Biology, 15(12)https://doi.org/110.1186/s13059-014-0550-8

84. Li HD, Lu C, Zhang H, Hu Q, Zhang J, Cuevas IC, Sahoo SS, Aguilar M, Maurais EG, Zhang S, Wang X, Akbay EA, Li GM, Li B, Koduru P, Ly P, Fu YX, Castrillon DH (2020) A PoleP286R mouse 
model of endometrial cancer recapitulates high mutational burden and immunotherapy response. $\mathrm{JCl}$ insight, 5(14)https://doi.org/10.1172/jci.insight.138829

85. T K, M R (2007) Enhancements and modifications of primer design program Primer3. Bioinformatics, 23(10):1289-1291. https://doi.org/10.1093/bioinformatics/btm091 